NBER WORKING PAPER SERIES

\title{
DO ENTERPRISE ZONES CREATE JOBS? EVIDENCE FROM CALIFORNIA'S ENTERPRISE ZONE PROGRAM
}

\author{
David Neumark \\ Jed Kolko \\ Working Paper 14530 \\ http://www.nber.org/papers/w14530 \\ NATIONAL BUREAU OF ECONOMIC RESEARCH \\ 1050 Massachusetts Avenue \\ Cambridge, MA 02138 \\ December 2008
}

We thank Marco Anderson, Eric Becker, Amy Ewing, Toni Feinstein, Matthew Gelbman, Ethan Jennings, Davin Reed, Mark Vasquez, and especially Jennifer Graves, Marisol Cuellar-Mejia, Ingrid Lefebvre-Hoang, and Smith Williams for outstanding research assistance. We also thank Toni Symonds and Frank Luera for many helpful discussions about California's enterprise zone program, and Daria Burnes, Joel Elvery, Mark Ibele, Magnus Lofstrom, Suzanne O'Keefe, Michael Teitz, seminar participants at UCI and the All-UC Labor Conference, and two anonymous reviewers for helpful comments, and Jonah Gelbach for supplying the code for the wild bootstrap computations. Neumark is also a Bren Fellow at the Public Policy Institute of California, a Research Associate of the NBER, and a Research Fellow at IZA, and gratefully acknowledges support from the Kauffman Foundation. The views expressed are the authors' alone, and do not represent the views of the Kauffman Foundation, of PPIC, or of the NBER.

NBER working papers are circulated for discussion and comment purposes. They have not been peerreviewed or been subject to the review by the NBER Board of Directors that accompanies official NBER publications.

(C) 2008 by David Neumark and Jed Kolko. All rights reserved. Short sections of text, not to exceed two paragraphs, may be quoted without explicit permission provided that full credit, including $\odot$ notice, is given to the source. 
Do Enterprise Zones Create Jobs? Evidence from California's Enterprise Zone Program

David Neumark and Jed Kolko

NBER Working Paper No. 14530

December 2008, Revised January 2010

JEL No. H25,H73,J23,R12

\section{ABSTRACT}

We use new establishment-level data and geographic mapping methods to improve upon evaluations of the effectiveness of state enterprise zones, focusing on California's program. Because zone boundaries do not follow census tracts or zip codes, we created digitized maps of original zone boundaries and later expansions. We combine these maps with geocoded observations on most businesses located in California. The evidence indicates that enterprise zones do not increase employment. We also find no shift of employment toward the lower-wage workers targeted by enterprise zone incentives. We conclude that the program is ineffective in achieving its primary goals.

David Neumark

Department of Economics

UCI

3151 Social Science Plaza

Irvine, CA 92697

and NBER

dneumark@uci.edu

Jed Kolko

Public Policy Institute of California

500 Washington St., Suite 600

San Francisco, CA 94111

kolko@ppic.org 


\section{Introduction}

State and federal enterprise zone programs are the principal means by which governments try to directly promote economic development in specific locations, typically economically-distressed urban areas. There is considerable debate over the effectiveness of enterprise zones in spurring job creation (e.g., Peters and Fisher, 2002). Evaluations of enterprise zone programs face several challenges, including precisely identifying the targeted areas, selecting appropriate comparison or control areas, distinguishing the effects of enterprise zones from other geographically-targeted policies, and choosing outcomes in line with program incentives and goals (e.g., Boarnet, 2001).

We evaluate the effectiveness of California's enterprise zone program, using new data sources that permit us to meet many of these challenges. The first data source is detailed GIS maps we constructed of the precise boundaries of enterprise zones as they evolved over time. With maps of both initial designations and expansion areas, we define the control areas in multiple ways, allowing us to perform sensitivity tests and to examine whether spillovers affect our results. The second is the National Establishment Time-Series (NETS) database, which includes employment and location information on nearly all business establishments in California in the period 1992-2004. By constructing precisely geocoded location information and combining this information with GIS maps, we can measure employment, the number of establishments, and other characteristics of these establishments in each year, in each enterprise zone and in appropriate control areas. In addition, we incorporate information on other geographically-targeted policies to try to isolate the effect of the state enterprise zone program.

\section{Limitations of Previous Research on Enterprise Zones}

Most existing research evaluating the effects of enterprise zones assesses their effects on jobs, businesses, or zone residents. Typically, these studies compare outcomes like employment (e.g., Bondonio and Engberg, 2000; O'Keefe, 2004) or number of establishments (Dabney, 1991) across enterprise zones and comparable regions where zone incentives do not apply. The results vary across studies. Many studies fail to find employment effects of enterprise zones, although some of the work (e.g., O'Keefe, 2004; and research reviewed in Wilder and Rubin, 1996) concludes that there are positive 
employment effects, at least in the short-run. Other recent work (Lynch and Zax, 2008; Elvery, 2009) provides thorough overviews of the literature. In this section, instead, we highlight the limitations of the existing research on which we try to improve in the present study. In the concluding section of the paper we provide some comparisons between our findings and the existing literature.

The first challenge in estimating the effects of enterprise zones is to identify geographic areas that precisely reflect enterprise zone boundaries for which outcomes of interest - such as employment - can be measured. In California and many other places, the boundaries of enterprise zones do not follow boundaries of census tracts, zip codes, or other standard geographic designations. Instead, studies have used aggregate data on zip codes (e.g., Dowall, 1996; Bondonio and Greenbaum, 2007) or census tracts (e.g., O'Keefe, 2004; Ham et al., 2009), the boundaries of which correspond only approximately to those of enterprise zones. These approximations, however, introduce measurement error by incorrectly assigning areas (and the workers or businesses in them) as inside or outside enterprise zones (Papke, 1993). For example, Elvery (2008) notes that for the two states he studies, if enterprise zones are defined as the areas encompassing all zip codes that overlap with enterprise zones, then the resulting enterprise zone definitions are six times larger than the actual zones. Similarly, he shows that, based on 1990 Census data and tracts, less than half of the population residing in census tracts that include enterprise zones actually live in enterprise zones. If locations are incorrectly classified as to whether or not they are in enterprise zones or control areas, there is likely a bias towards finding no effect of enterprise zones.

The second challenge is selecting appropriate control groups for enterprise zones. The ideal control group consists of areas economically similar to enterprise zones but lacking enterprise zone designation. Some studies, however, have used broad control groups that may preclude meaningful comparison with the enterprise zones. For instance, Peters and Fisher (2002) estimate the effects of enterprise zones in a number of states relative to the areas of states outside the enterprise zone; similarly, Lynch and Zax (2008) use all regions of Colorado that are not in enterprise zones. ${ }^{1}$ Others have constructed control groups differently, matching enterprise zone areas to control areas without enterprise zones based on

\footnotetext{
${ }^{1}$ By ignoring births and relocations, this study may miss an important role played by births in job growth.
} 
characteristics of the zones or simply nearness to the zone. O'Keefe (2004) matches census tracts that approximate enterprise zone boundaries to other census tracts using propensity score matching based on residential and employment characteristics. However, propensity score matching does not account for unobservable sources of differences in job growth that may be the basis for assignment to zones. In addition, for many of the zones the matching is on post-treatment observations, which implies that her matching may mask the effects of enterprise zones by conditioning them out. ${ }^{2}$ Elvery (2009) improves on this propensity score strategy by matching on the employment variation across neighborhoods that is not accounted for by residents' characteristics, and by matching on pre-treatment observations. None of these studies makes use of before and after comparisons of areas observed both before and after enterprise zones were established. Other studies use these matching strategies with before and after comparisons. ${ }^{3}$

More recent research has addressed the comparison group problem in ways that try to identify more reliable control groups. Billings (2009) uses a spatial discontinuity model, looking at employment growth in Colorado's enterprise zones within $1 / 4$ mile of the zone boundary and using the area outside the zones within $1 / 4$ mile of the zone boundary as the control group. ${ }^{4}$ Busso and Kline (2007) compare residential employment outcomes in census tracts that became part of federal empowerment zones with outcomes in census tracts that submitted unsuccessful applications to be designated empowerment zones; they also in some cases do comparisons with areas that become parts of zones in the future. Hanson (2009) also compares employment outcomes in federal empowerment zones with unsuccessful applicant areas, and then he goes a step further by instrumenting for zone applicant success using measures of the political influence of the zone's Congressional representative. His IV results show no statistically significant effect on employment of federal empowerment zones, even though his OLS results - using unsuccessful applicant zones as a control group - show a positive employment effect. In earlier work, Boarnet and

\footnotetext{
${ }^{2}$ Moreover, O'Keefe matches on employment levels, whereas we would like to hold employment growth rates (in the pre-treatment period) constant between treatment and control groups. Bondonio and Greenbaum (2007) also use propensity score methods, but their study is limited to manufacturing establishments.

${ }^{3}$ See Papke (1994), Greenbaum and Engberg (2004), and Ham et al. (2009).

${ }^{4}$ Billings uses geographic methods most similar to ours, with digitized maps of enterprise zone boundaries and geocoded establishment locations.
} 
Bogart (1996) study a set of municipalities in New Jersey, all of which qualified for enterprise zones. They compare those that received zones to all that qualified, and, paralleling Busso and Kline, also compare those that received zones to those that qualified and applied for zones but did not receive them; however, this study suffers from poor delineation of enterprise zones by using entire municipalities.

The third challenge is that an enterprise zone program may cover areas that are also affected by other geographically-targeted policies, including other local or state policies or federal enterprise zone programs. If another program has strong effects and in some areas targets both the treatment and control areas used to estimate the effects of enterprise zones, then ignoring the effects of the other program will lead to biased estimates of the effects of enterprise zones. We are not aware of studies that have simultaneously considered the effects of programs that apply to overlapping areas.

Finally, the fourth challenge is to study outcomes that are appropriate - and appropriately measured - given the enterprise zone program's goals and design. It is also essential to identify which businesses and households qualify for program incentives. For example, in California's program businesses in an enterprise zone can claim hiring credits for employees living in a targeted employment area (TEA), which need not be coincident with the enterprise zone. Hence, evaluating the program in terms of employment or other labor market outcomes of zone residents (as in Ham et al., 2009) would be less appropriate, as the effects of California's enterprise zones on household outcomes, like employment or poverty, should be more apparent in TEA's. In contrast, for asking whether the state's enterprise program boosted employment - when measured by the location of jobs - it is appropriate to look at enterprise zones.

\section{California's Enterprise Zone Program}

California's enterprise zone program has multiple goals: attracting jobs and businesses and raising employment is one goal, while others include reducing poverty and unemployment and raising incomes in target areas. ${ }^{5}$ These multiple goals - job creation and improving residents' circumstances - stem from the 1996 merger of two precursor programs that gave rise to the current enterprise zone program: the Enterprise Zone Act, which provided incentives to businesses located in specific areas (and which led to

\footnotetext{
${ }^{5}$ See Assembly Jobs, Economic Development, and the Economy Committee (2006, p. 5).
} 
the creation of the original enterprise zones); and the Employment and Economic Incentive Act, which provided incentives to businesses that hired employees living in distressed residential areas.

The program seeks to accomplish these goals by providing a variety of tax incentives to businesses located in designated areas to encourage the hiring of economically disadvantaged workers and to spur the creation of businesses. The largest incentive is state tax credits for hiring a "disadvantaged" employee; this credit is available for those hired after the zone is designated. ${ }^{6}$ The state calculates the allowable hiring credit as a share of wages up to $150 \%$ of the minimum wage; the allowable credit is $50 \%$ of qualified wages in the first year, falling by 10 percentage points each year until reaching zero after five years. ${ }^{7}$ Workers qualify as "disadvantaged" if they are unemployed for a sufficient duration or for certain other reasons - for example, if they have sufficiently low income, if they belong to one of several "eligibility groups" (veteran, enrolled in welfare-to-work, etc.), or if they live in a targeted employment area. ${ }^{8}$ Given that disadvantaged workers are likely to earn low wages, the tax credit can result in a substantial reduction in the cost of hiring low-skill labor. For example, at a $\$ 6$ minimum wage, the credit would reduce the cost of a full-time worker earning $\$ 9$ per hour by $\$ 9,000$ in the first year, $\$ 7,200$ in the second year, etc. Another way to think about this is that the cost of hiring new low-skilled workers who are likely to turn over within a year is reduced by $50 \%$, which is much more than the labor cost change associated with other policies about which there is lively debate regarding employment effects (e.g., health insurance mandates, discussed in Burkhauser and Simon, 2008). ${ }^{9}$

The program offers four other incentives: (1) an income tax credit for sales or use taxes for machinery or parts for use within the zone; (2) a longer period (15 years versus 10 years) in which

\footnotetext{
${ }^{6}$ See, e.g., http://www.mcedco.com/FAQ\%20Enterprsie\%20Zone.pdf (viewed November 28, 2009).

${ }^{7}$ This reduction over five years in the hiring credit is relative to when the worker is hired, not relative to when the enterprise zone is designated. Thus, the structure of the hiring credit does not have implications for the timing of employment effects over the life of the enterprise zone.

${ }^{8}$ The eligibility of residents of targeted employment areas (TEA's) for the hiring credit began in 1997. Enterprise zones are defined by individual street addresses. TEA's are defined by census tracts. TEA's often include parts of an enterprise zone itself along with other lower-income neighborhoods, but they are defined independently of enterprise zones and do not necessarily overlap with them. A worker living in a TEA qualifies for the hiring credit regardless of the worker's characteristics. TEA's include census tracts where more than half the population earns less than 80 percent of median area income, according to the 1980 Census.

${ }^{9}$ See Engberg and Greenbaum (1999) for a description of subsidies in other states.
} 
businesses can carry forward net operating losses into future years to reduce tax liabilities; (3) accelerated depreciation of depreciable property; (4) a tax credit of 5\% of qualified wages that low-income employees can claim, up to a maximum and subject to restrictions on work for the business in the zone and services performed within the zone. ${ }^{10}$ Each of these incentives is intended to reduce the tax burden or costs for businesses located in enterprise zones, which might be expected to spur the creation of new businesses or the expansion of existing ones. In addition, businesses in enterprise zones can sometimes receive preferential treatment on state contracts. Finally, financial lenders may deduct from their income net interest received from loans made to businesses in enterprise zones.

Localities apply to the Department of Housing and Community Development (HCD) to have a geographic area designated as an enterprise zone. Eligibility criteria include job-generating capacity as well as the level of economic distress measured along a number of dimensions. New zones are selected by HCD from the eligible areas based on these and other factors, including the local applicant's plan for bundling other local incentives, administering the program, and evaluating the outcome. There are some minimum criteria for enterprise zone designation - such as, for example, whether an area has recently experienced a particularly sharp decline, or conversely exhibited promise for growth - but beyond that the process is not formulaic and appears to rely on subjective assessments.

As of the period covered by this paper, the enterprise zone program allowed for up to 42 zones in the state. HCD can conduct an application process when the number of zones falls below the maximum, whether due to zones expiring, zones being de-designated, or the legislature increasing the maximum number of zones.

Ten enterprise zones were created at the program's inception in 1986; since then, legislation has increased the number to 42 . Zones are designated for an initial 15-year term, after which 5-year extensions can be granted. After the 15- or 20-year period, the enterprise zone expires, and a new application must be submitted. In practice, there is very little turnover in enterprise zones. All of the zones

\footnotetext{
${ }^{10}$ Although technically this credit is given to the worker, the incidence of the tax credit is independent of who claims it. As long as labor supply is not completely inelastic, market wages should fall (although wages plus the credit will rise), and employment increase.
} 
designated before 1990 were granted 5-year extensions when they reached the end of their original 15year terms. Zones have expanded periodically, and in 1998 many enterprise zones were allowed a onetime expansion of their boundaries by up to $20 \%$ (which they could undertake later). No enterprise zone in the state has ever been de-designated for poor audit results or any other reason. ${ }^{11}$ Furthermore, the application process is sometimes uncompetitive: in the 2006 application round, when 23 of 42 enterprise zone slots were open, HCD received 25 applications and ended up combining several applications so that all 25 applicants became part of 23 newly designated zones - and many of these were in localities where a zone recently expired.

Our study focuses on the effects of enterprise zones on jobs and businesses located inside the zones, emphasizing the question of whether enterprise zones spur job growth. Job creation is an explicit goal of the program, and is also presumably a prerequisite for improving the economic circumstances of the disadvantaged workers the program is intended to help. In addition, in a survey of local zone managers, nearly all respondents cited job or business creation when asked an open-ended question about the purpose of the enterprise zone program; far fewer cited improving residents' outcomes such as unemployment or poverty (Kolko and Neumark, 2010).

Our study does not directly assess evidence of the effects on residents of the enterprise zones or of targeted employment areas (or on other individuals meeting eligibility for the hiring tax credit). The effects on zone residents per se are not the best metric for evaluating the policy, since the zones do not explicitly target these residents. As already noted, although the effects on residents of targeted employment areas are more relevant (since 1997), the first-order question, it seems to us, is whether enterprise zones lead to job creation. If they do, then an important next step would be to ask whether the gains accrue to those who are targeted by the policy. We do, though, indirectly assess the question of whether enterprise zones likely help these disadvantaged workers, by asking whether the enterprise zone incentives affect the composition of employment in a manner that is more likely to be consistent with helping those who are socioeconomically disadvantaged.

11 See Assembly Jobs, Economic Development, and the Economy Committee (2006, p. 10). 


\section{Data, Mapping, and Methods}

The challenges faced by research on enterprise zones played a central role in shaping the methods and approaches we use in this paper. With regard to the first challenge - precise identification of zone boundaries - we digitally map California's enterprise zones street-by-street rather than approximating by using census tracts, zip codes, etc. Of course the precise geographic contours of enterprise zones that we create are only useful if we can map business establishments or employment into them. The NETS data are uniquely suited to this task, as they include exact street addresses that we have geocoded to precise geographic locations.

The second challenge concerns the selection of appropriate control groups. We use two approaches. One approach we use is similar to Billings (2007) in that we consider a narrow buffer just outside the enterprise zone as a control group. Our second approach is to use only areas that are ever included in enterprise zones, exploiting variation in when the areas were added owing to the ability of California's enterprise zones to expand numerous times. For example, we use areas that are later added to enterprise zones as control groups for areas original to (or added earlier to) the same enterprise zone. This has parallels with some of the analyses of federal zones in Busso and Kline (2007). In our view, this latter approach provides the most reliable estimates. In addition, we estimate heavily-saturated regression models to account for remaining possible differences between treatment and control areas.

The third challenge is accounting for other geographically-targeted policies, which we address by also digitizing maps of the areas affected by two such policies that are particularly important. The most extensive is redevelopment areas, which are designed to encourage property development that removes urban blight. ${ }^{12}$ Cities and counties in California administer hundreds of redevelopment agencies (Dardia, 1998). Many of these redevelopment areas partially overlap with or are adjacent to enterprise zones. In addition, there are three federal programs - Renewal Communities, Enterprise Communities, and

\footnotetext{
12 Activities qualifying for redevelopment area benefits include the "rehabilitation/reconstruction of existing structures, the redesign/replanning of areas with inefficient site layout, the demolition and clearance of existing structures, the construction/rehabilitation of affordable housing and the construction of public facilities including, but not limited to, public buildings, streets, sidewalks, sewers, storm drains, water systems and street lights" (California Redevelopment Association, 2008). Redevelopment is typically financed via tax-increment revenue.
} 
Empowerment Zones - with a variety of benefits similar to those in state enterprise zones. ${ }^{13}$ These can also overlap with enterprise zones or our control areas.

And finally, with regard to the fourth challenge - using appropriate outcome variables defined for the right areas - we focus on the effects of enterprise zones on job growth in the zones compared to control areas. We also examine their effects on establishment counts and the composition of employment. In particular, because the hiring credit is capped per worker, firms in industries that hire lower-wage workers would see their labor costs reduced by a higher percentage than firms in high-wage industries, and the program's tax incentives that target machinery and property are most likely to benefit manufacturing enterprises. We therefore estimate the effects of enterprise zones on the shares of employment in low-wage industries or manufacturing. The next two subsections explain the mapping procedures and the statistical models we use.

\subsection{Data and Geographic Methods}

We use the National Establishment Time-Series (NETS) database and GIS software to address many of the difficulties and complications that arise in delineating the boundaries of areas affected by enterprise zone incentives, and measuring the effects of these incentives on affected businesses. The NETS is a national, longitudinal file of the universe of business establishments, created by Walls \& Associates using establishment-level data from Dun \& Bradstreet. Our extract of the NETS covers all of California over the period 1992-2004. The NETS has a couple of central features that make it well-suited to studying the effects of California's enterprise zones. First, it provides exact street addresses for establishments in every year, allowing us to identify location precisely rather than having to aggregate to the tract or zip code level, once the enterprise zones are mapped. Second, it includes detailed industry information, allowing us to look not only at changes in the level of employment and number of establishments but also in the composition of employment. ${ }^{14}$

\footnotetext{
${ }^{13}$ For discussion of federal benefits, see Busso and Kline (2007), U.S. Department of Housing and Urban Development (2003), and http://www.hud.gov/offices/cpd/economicdevelopment/programs/rc/about/timeline.cfm (viewed October 10, 2006).

${ }^{14}$ Neumark et al. (2007) conducted a detailed investigation of the quality of the NETS data along numerous
} 
Preparing the data for analysis involved two processes: digitizing enterprise zone maps (as well as maps for areas covered by other policies), and geocoding establishments in the NETS so that they can be mapped. The geocoding is fairly standard and is explained in Appendix A. The mapping, however, is unique and is central to this research, and so we explain it in some detail.

\subsubsection{Mapping Enterprise Zones and Businesses}

Mapping establishments to enterprise zones requires GIS maps ("shapefiles") of the zones, and our identification strategy requires historical as well as current maps in order to distinguish original zone definitions from expansion areas. As these shapefiles are not available, we had to create historical and current enterprise zone maps from official lists of street address ranges and the years they were included in the zone; these lists are provided by local zone administrators to HCD. ${ }^{15}, 16$ Table 1 lists the enterprise zones in the state, the years when they were initially designated, and the number of expansions (if any). The table also shows a handful of enterprise zones - mainly smaller ones - for which the street list information was either unavailable or inconsistent and which were therefore dropped from the analysis.

Because the date each address range was added to the zone is contained in the underlying data for each hypothetical address, we can select street ranges for the year in which the street range would have entered the zone. Figure 1 displays the results for the San Diego Barrio Logan zone. The grey streets represent the original zone (1987), and the black streets represent the first expansion to the zone (1991) as well as the second expansion in 1998, which in this case added only a tiny area which we do not distinguish separately in the figure. ${ }^{17}$ This map also illustrates that a simple polygon of the outer boundary by year would miss much detail. There are streets that were not included in the original zone

dimensions, including issues raised in earlier criticism of the Dun \& Bradstreet data from which the NETS is constructed (Davis et al., 1996). They concluded that the NETS by and large provides reliable measurement of employment levels, births and deaths, business relocations, etc.

15 Available at http://www.hcd.ca.gov/fa/cdbg/ez/enterprise/ (viewed November 1, 2006). These lists are used by California's Franchise Tax Board to determine whether establishments qualify for benefits. In some cases date ranges were missing or ambiguous in the files listed on the HCD webpage, in which case we contacted zone administrators directly to obtain the requisite information. In the majority of cases zone administrators were able to provide us with clarifying information.

${ }^{16}$ We also had to develop methods for the selection of street address ranges in GIS; these methods are described in Appendix B of the working paper version of this paper (Neumark and Kolko, 2008).

17 Although many expansions are minor, many are also substantial, and expansions account for more than onequarter of employment in areas that are ever in enterprise zones, as discussed below with reference to Table 4 . 
that are between zone streets or in areas largely surrounded by zone streets. If we simply used outer boundaries we would have some misclassification of areas. In fact these largely surrounded streets in some cases constitute significant parts of the control areas that we use in our analysis. There are a handful of cases where we are unable to determine if a street belongs in a zone. This can occur if a street is not listed as belonging to a zone but appears to be completely surrounded by streets in the zone, which happens, for example, when a street has been developed subsequent to zone designation or expansion but the street lists from HCD do not yet reflect this information. For the main analysis we exclude these questionable streets, but we also verify that our analysis is not affected by including them in the zones.

After creating the GIS shapefile with all zone streets, we display the zone streets and the geocoded businesses in the same map and then select businesses based on their location, by year, in the enterprise zone treatment or control areas. Because geocoded longitude and latitude assigned to establishments corresponds to the center of the street on which they are located, some modifications had to be implemented for the correct classification of whether a business was inside an enterprise zone for streets on the boundaries of zones, by determining on which side of a street a business was located. ${ }^{18}$

Overall, our approach to determining whether businesses are in or out of a zone in each year was successful. We checked the error rate by comparing the final variable created to indicate zone status in various years against the original zone ranges from the street address lists for San Diego (a city zone) and Yuba Sutter (a rural zone), for random samples of observations, finding both to have error rates of less than $1 \%$. However, our approach was more problematic for the zones in Los Angeles, for which the mapping of enterprise zones was much more complicated because of the large numbers of street ranges (covering 103 pages) and the four separate zones in the city. We had to modify our mapping procedures to handle this complexity, and in part as a result of these complications and modifications, for Los Angeles we end up with a classification error rate in the 5-6\% range. ${ }^{19}$

\footnotetext{
18 These modifications are described in Appendix C of Neumark and Kolko (2008).

${ }^{19}$ Appendix D in Neumark and Kolko (2008) provides more detail on the complexities and problems with the Los Angeles zone as well as our modifications.
} 


\subsubsection{Mapping Redevelopment Areas and Federal Zones}

Redevelopment areas are included in the analysis if they are located within one mile of an enterprise zone boundary. For each enterprise zone, the overlapping and surrounding redevelopment agencies were found by combining information from the California State Controller's Office's Redevelopment Agencies Annual Report ${ }^{20}$ with information from Google Maps, to determine which redevelopment agencies within that enterprise zone's county were located near that enterprise zone. We then contacted the agencies online or by phone to obtain maps of the redevelopment areas administered by that agency. These maps could take a few forms, including GIS files, PDF files, or paper maps. We used information from the agencies and the Controller's report to determine when areas had been created, when they would expire, and where the area boundaries changed during the study period. We then used the maps and this information to create the final files for use in the analysis. If GIS maps were available, we edited these as necessary if there were boundary changes not reflected in the most current map. This might involve cutting existing polygons or creating new polygons using GIS software. If PDF or paper maps were available, we used these to draw polygons that corresponded to the maps. ${ }^{21}$ Then, as for the maps of enterprise zones, we added dates to each polygon. ${ }^{22}$

Information on the locations of federal designated zones comes from the U.S. Department of Housing and Urban Development. ${ }^{23}$ These zones are listed in Table 2. We added beginning and ending

20 Table 2, http://www.sco.ca.gov/ard/local/locrep/index.shtml (viewed August 28, 2008).

${ }^{21}$ Drawing and editing polygons was done utilizing StreetMap, following the boundaries in the redevelopment area maps. Streets were followed down the center if the area boundary followed the center of the street or about 30 feet to either side if the area included both or neither sides of the street. This ensured that establishments, which were geocoded to be located 10 feet from the center of the street, were properly included in or excluded from the area. The points that connect the edges of the polygons were placed along the streets as closely as was required to ensure that the boundary was less than 10 feet from the center of the street if the boundary included one side or more than 30 feet from the center of the street if the boundary included both or neither sides. This placement depended on how much the streets curved. There were some areas for which it was impossible to tell from the map, from the boundary description, or from talking with people at the redevelopment agency whether the boundary followed the center of the street or included both sides of the street. For these areas the boundary was drawn down the center of the street. 22 For one redevelopment area, overlapping with the Lindsay enterprise zone, we were unable to obtain maps or descriptions of its original 1986 or its amended 1993 boundary and only obtained those for its amended 1995 boundary. We use the 1995 boundary for all years of the analysis.

23 Specifically, we use GIS boundary files that were available from the HUD website (http://www.hud.gov/offices/cpd/economicdevelopment/programs/rc/tour/ca/index.cfm, viewed July 20, 2007). The files have since been removed and replaced with tables containing the 1990 and 2000 census tracts that make up the 
dates for each area to the resulting polygon for each federal designated community. There are some designated communities that changed status during the period of analysis. However, because we treat these federal programs identically in terms of their potential economic impact, the beginning date assigned to each zone is the first year when they were designated federally. ${ }^{24}$ As an example of the combination of all of the information on geographically-targeted incentives, Figure 2 displays the redevelopment areas, the federal zones, and the state enterprise zone streets for Santa Ana.

\subsection{Statistical Approach}

For any enterprise zone, we define a set of subzones consisting of the original zone plus each expansion. An observation, then, is a subzone-year pair. For example, suppose that a zone is designated in year 1 , and expands only once, in year 5, and that there are 10 years of data. Then this zone contributes 20 observations - 10 years of observations on the originally-designated area, and 10 years of observations on the expansion area.

Our estimates of the effects of enterprise zones come from comparing changes in outcomes associated with an area becoming designated as an enterprise zone to changes in areas for which enterprise zone status does not change. Because economic conditions vary across areas, it is important to identify an appropriate control group. One approach we use is to restrict attention to a very narrow control ring. In particular, based on our GIS maps of enterprise zones, we choose an area of fixed, relatively small distance from the outer boundary of an enterprise zone - 1,000 feet - on the presumption that economic conditions, aside from the effects of the enterprise zone, are likely to be very similar in the treated area that became an enterprise zone and the surrounding, nearby control area. ${ }^{25}$ To illustrate, Figure 3 shows the map for the Santa Ana enterprise zone, displaying the initially-designated streets, the expansion streets, and the 1,000-foot control ring. When we include control rings, we generate an additional

Renewal Communities, Empowerment Zones and Enterprise Communities (http://www.hud.gov/offices/cpd/systems/mapping/rcezec/boundaryfiles/metadata.htm, viewed September 30, 2008). This information still allows creating the RC/EZ/EC boundaries and incorporating them into GIS.

${ }^{24}$ For the same reason, although Los Angeles has both a Renewal Community and an Empowerment Zone, we have appended the two together.

${ }^{25}$ In some sensitivity analyses, we also report results using a 2,500-foot control ring. Because the results are insensitive we did not explore using different dimensions for this control ring. 
observation for each year's data on each control ring; we also refer to the control ring as a subzone.

A second and potentially more reliable source of identifying information comes from variation strictly within the zone. In particular, we can compare what happens when an area of a zone is designated relative to changes in areas that were designated earlier or will be designated later. This identifying information is likely even more reliable because the control areas consist only of areas that were included in the zone at some point during the sample period. That is, it has been demonstrated through the policy process that the areas in the control groups used for this analysis were appropriate for enterprise zone designation. In contrast, the area outside a zone might already have been conducive to job growth, which is why it was not included. In that case, comparing what happened in designated areas to what happened in the control ring could suggest that enterprise zones reduced employment, even if this was not their actual effect. Alternatively, perhaps the area outside the zone was not conducive to job growth, and that is why the area was omitted. In this case we would have the opposite bias - overstating the positive impact of enterprise zones. But because expansion areas eventually do become part of the enterprise zone, omitting the control rings and focusing only on initial designation and expansion areas should reduce the bias: areas that eventually all became part of a zone should be more similar to each other than to the control ring, which never becomes part of the enterprise zone. In our view, this is the principal advantage of our identification strategy, which relies on areas that would become or earlier became parts of enterprise zones, compared to, for example, propensity score methods matching on characteristics of areas inside and outside zones. ${ }^{26}$

We index the geographic locations corresponding to each enterprise zone by $j=1, \ldots, J$, which include the zone itself and can include the control ring. We have observations over time, indexed by $t=1$, $\ldots, T$. We define subzones within $j$, indexed by $k$, with $k=0, \ldots, K_{j} ; k=0$ for the part of $j$ that is never in

\footnotetext{
${ }^{26}$ As noted earlier, the two best-known prior published studies of California's enterprise zone program use propensity score methods (Elvery, 2009; O'Keefe, 2004). Another issue with using propensity score methods is that once one takes the approach of using actual street maps to define the zone boundaries accurately (rather than, for example, approximating with census tracts), it becomes much more difficult to think about using a matching approach, since there are no well-defined geographic areas to compare with the areas encompassed by enterprise zone streets.
} 
a zone, and $k=1, \ldots, K_{j}$ for the parts that become a zone initially and with each expansion. The dependent variable $Y_{j k t}$ is, for example, the log of the number of jobs in a subzone. We denote by $E Z_{j k t}$ a dummy variable for whether a location $k$ in area $j$ is in an enterprise zone in year $t$. So for the part of area of $j$ that is never in the zone, $E Z_{j k t}=0$ for all $t$; in a sub-area that becomes a zone in $t^{\prime}, E Z_{j k t}=0$ for all $t<t^{\prime}$, and $E Z_{j k t}=1$ for all $t \geq \mathrm{t}^{\prime}$; and for the part that is always a zone in our sample period, $E Z_{j k t}=1$ for all $t$.

We begin by estimating a model in levels, in which enterprise zone designation of a subzone shifts the level of the dependent variable, as in:

$$
Y_{j k t}=\alpha+\beta E Z_{j k t}+\sum_{j^{\prime}=1}^{J} \sum_{k^{\prime}=0 o r 1}^{K_{j}} D_{j^{\prime} k^{\prime}} \lambda_{j^{\prime} k^{\prime}}+\sum_{t^{\prime}=1}^{T} D_{t^{\prime}} \theta_{t^{\prime}}+\sum_{j^{\prime}=2}^{J} \sum_{t^{\prime}=1}^{T}\left\{D_{j^{\prime}} \cdot D_{t^{\prime}}\right\} \tau_{j^{\prime} t^{\prime}}+\varepsilon_{j k t} .27
$$

The parameter of interest is $\beta$, which measures the effect of enterprise zones on the outcome $Y . \mathrm{D}_{\mathrm{jk}}$, $D_{t}$, and $D_{j}$ are dummy variables for each subzone, year, and enterprise zone, respectively. The dummy variables $D_{j k}$ capture differences common to each subzone, to control for any characteristics (education levels, industry mix, infrastructure, land area, etc.) that are time-invariant. ${ }^{28}$ The dummy variables $D_{t}$ capture aggregate changes, accounting for the possibility that enterprise zones tended to be established in periods of either particularly high or low employment (or establishment) growth across all of the regions included in our sample. The term $D_{j} \cdot D_{t}$ allows for enterprise zone-specific changes over time in the outcome $Y$, to allow for an arbitrary pattern of changes over time across the broad area covered by a zone, its expansions, and the associated control ring (when included). Given that we identify effects off of subzone-level variation, we can allow these arbitrary changes over time for each enterprise zone $j$ and still identify $\beta$.

We also estimate a version of equation (1) in which we control even more richly for differences across subzones by adding subzone-specific linear time trends, in the form of interactions between the subzone dummy variables $\left(D_{j k}\right)$ and a linear time trend. This specification allows for the possibility - in an unrestricted fashion - that each subzone had different underlying rates of growth of either employment

\footnotetext{
${ }^{27}$ Note that the sum over $k$ ' begins with zero if the control ring is included, and one if it is not.

28 When we include the control rings, the dummy variables for each control ring will account for these differences relative to the areas that became parts of enterprise zones.
} 
or the number of businesses. Note that we can add interactions between time and the subzone dummy variables $\left(D_{j k}\right)$ as long as we use a parametric specification of time; we cannot of course introduce a full set of subzone-year interaction dummy variables and still identify $\beta$.

Because we allow separate dummy variables for each subzone, an area $j k$ that is in an enterprise zone for the entire sample period contributes nothing to the identification of $\beta$, as $D_{j k}$ and $E Z_{j k t}$ are identical for all $t$. In this case, we have a pure difference-in-differences estimator that identifies $\beta$ only from subzones that change status, relative to those that do not. Because the data begin in 1992, whereas most zones were originally designated prior to that year, much of our identifying information comes from expansions. ${ }^{29}$ Thus, interpreting our results as estimating "the" effects of enterprise zones hinges on the assumption that the effects of original designations and expansions are the same. ${ }^{30} \mathrm{We}$ present some results that seek to separately identify the effects of initial zone designations and expansions, and find no significant evidence of differences. In the absence of pre-1992 employment data, we cannot of course assess whether the effects of initial designations and expansions prior to 1992 are different from those we can study.

While equation (1) specifies the effects of enterprise zones as a one-time shift in the level of the dependent variable, an alternative possibility is that enterprise zones shift the growth rate of employment. To explore this possibility, we instead estimate the model for the first-difference of $Y$ :

$$
\Delta Y_{j k t}=\alpha+\beta E Z_{j k t}+\sum_{t^{\prime}=1}^{T} D_{t^{\prime}} \theta_{t^{\prime}}+\sum_{j^{\prime}=2}^{J} \sum_{t^{\prime}=1}^{T}\left\{D_{j^{\prime}} \cdot D_{t^{\prime}}\right\} \tau_{j^{\prime} t^{\prime}}+\eta_{j k t} .
$$

In this specification, $\beta$ measures the shift in the growth rate of outcome $Y$ associated with enterprise zone designation. We have dropped the subzone dummy variables $D_{j k}$ from this specification because

\footnotetext{
${ }^{29}$ For three of the 26 zones, there is no expansion and the original zone was created before the first year for which NETS data are available, implying that only 23 zones contribute identifying information.

${ }^{30}$ In our survey of local enterprise zone administrators, we asked why zones expanded when and where they did. Two main reasons emerged. First, zones often expanded to benefit businesses that were moving to or growing in areas just outside the enterprise zone. Second, zones sometimes expanded to incorporate areas newly designated as commercial or industrial by the local planning process. To the extent that zones expanded where businesses planned to relocate or grow, zone expansions were sometimes the effect rather than the cause of employment growth; thus, our estimates of the effect of the enterprise zone program on employment would be biased upward, strengthening our findings of no positive employment effects of enterprise zones.
} 
equation (2) can be viewed as the first-difference of a version of equation (1) in which enterprise zone designation affects the growth rate of the dependent variable rather than the level. ${ }^{31,32}$ We also estimate the model with these subzone dummy variables added back in, which corresponds to the first-differenced version of equation (1) when it includes subzone-specific linear time trends.

In addition, we estimate models that allow enterprise zone designation to shift both the level and growth rate of the dependent variable. The corresponding equation is:

$$
\Delta Y_{j k t}=\alpha+\beta E Z_{j k t}+\beta^{\prime} E Z D_{j k t}+\sum_{t^{\prime}=1}^{T} D_{t^{\prime}} \theta_{t^{\prime}}+\sum_{j^{\prime}=2}^{J} \sum_{t^{\prime}=1}^{T}\left\{D_{j^{\prime}} \cdot D_{t^{\prime}}\right\} \tau_{j^{\prime} t^{\prime}}+\eta_{j k t} .
$$

In this model, $E Z D_{j t k}$ is a dummy variable that is equal to one only in the year in which a subzone becomes designated as part of the zone. Thus, this equation augments equation (2) by allowing a discrete jump in the level of $Y$ in the year the subzone is designated in addition to the constant effect of enterprise zone designation on the growth rate that equation (2) imposes. Thus, this is a more flexible version of the previous model. As in the other specifications, we also estimate this model including the subzone dummy variables to allow for subzone-specific linear trends.

We account for other geographically-targeted policies in two steps. First, we redefine subzone-year pairs to represent status with regard not only to whether and when they became part of an enterprise zone but also whether and when they became part of a redevelopment area or federal zone. As a result, there are far more subzones. Second, we modify the above specifications to include dummy variables indicating whether each subzone $k$ is in a redevelopment area (or federal zone) in year $t$. We also include the

\footnotetext{
${ }^{31}$ Specifically, in equation (1) the enterprise zone treatment is captured in the dummy variable $E Z_{j k t}$. Suppose instead that the enterprise zone variable in equation (1) was the product of $E Z_{j k t}$ and the number of years the subzone has been designated an enterprise zone, denoted $t_{D}$; in this specification the growth rate of the dependent variable shifts when $E Z_{j k t}$ switches from zero to one. Because the first difference of $E Z_{j k t} t_{D}$ is just $E Z_{j k t}$, the first-differenced version of equation (1) with $E Z_{j k t} t_{D}$ substituted for $E Z_{j k t}$ yields equation (2). (In principle, we need to first difference the year dummy variables and the zone-year interactions including in equation (1). But doing so gives the identical fit to leaving in the original dummy variables, as long as we leave the intercept in the first-differenced model.) 32 In Kolko and Neumark (2010) we reported estimates of how the effects of enterprise zones vary with zone characteristics. Some of our specifications used a model like the one described in the previous footnote (in levels, with an interaction between $E Z_{j k t}$ and a linear trend). However, we used a simple linear trend starting with a value of one in 1992, rather than in the year in which the subzone was designated, and it is the latter that leads directly to the model for the first-difference in equation (2). We have re-estimated these interactive effects in Kolko and Neumark (2010) using the latter specification instead. The conclusions are unchanged (results available from the authors upon request).
} 
enterprise zone dummy variables as well as interactions between these. Thus, we do not restrict the effects of the different kinds of zones to be additive, but rather allow for the possibility, for example, that state enterprise zone benefits have different effects if the state enterprise zone overlaps with a federal zone.

In all of the estimations, to allow for arbitrary correlations over time within areas and across observations on the subzones of each zone, we use standard errors that cluster on the enterprise zone only; this also allows for different error variances across zones. Our tables report the standard cluster-robust standard errors. However, as noted above, we do not have data on a large number of zones, so the usual asymptotics under which these standard errors are consistent, and confidence intervals therefore provide the correct coverage, may not apply. Cameron et al. (2008) have shown that using the wild bootstrap, modified to account for clustering, ${ }^{33}$ provides confidence intervals for the $t$-statistics based on the standard cluster-robust standard errors with coverage probabilities that are approximately correct even when the number of groups (zones, in our case) is quite small. ${ }^{34}$ In addition to the standard cluster-robust standard errors, therefore, we have also calculated these bootstrapped confidence intervals, and in each table report whether the estimated effects of enterprise zones are statistically significant at various significance levels based on the bootstrap results. As it turns out, some differences emerge, but very rarely for the employment results.

\section{The Effects of Enterprise Zones}

\subsection{Enterprise Zone Employment and Establishments in the Context of the State's Economy}

Table 3 presents descriptive information on the enterprise zones we study. Column (1) reports employment in each enterprise zone in our sample as of 2004. The zones are sorted from highest to lowest employment levels. As reported at the bottom of column (1), overall employment statewide in these enterprise zones is about 1.38 million, and employment in the control rings used in our empirical analysis (extending 1,000 feet from the zone boundaries) is about 580,000. Overall, employment in the counties in

\footnotetext{
${ }^{33}$ In particular, the bootstrapping is on the clusters rather than the individual observations.

${ }^{34}$ In their Monte Carlo simulations, when the number of groups is in the 20's, confidence intervals based on the standard cluster-robust standard errors are fairly accurate; but this result need not carry over to our particular specification.
} 
which the zones we study are located is 12.6 million, so that enterprise zone employment is about $11 \%$ of the total. Statewide employment in 2004, based on the NETS data, was 16.4 million, and employment in all counties with enterprise zones - whether or not we could construct maps for those zones - was about 14.2 million. Thus, if we assume that the share of county employment represented by enterprise zones is the same in the counties for which we do not have zone maps as for the counties for which we could construct these maps, then our enterprise zones represent $89 \%(12.7 / 14.2)$ of enterprise zone employment in the state. Columns (2)-(4) provide information on enterprise zone employment relative to county and statewide employment. The shares of enterprise zones in county employment vary a good deal across counties, varying from a high of $52.8 \%$ in Shasta Metro to a low of $0.7 \%$ in Altadena/Pasadena. Column (4) indicates that the large zones (Los Angeles, San Francisco, Santa Ana, and Oakland) each account, on their own, for $1 \%$ or more of total statewide employment. ${ }^{35}$

\subsection{Enterprise Zones: Initially-Designated Areas, Expansions, and Control Rings}

Table 4 reports some figures for the sample as a whole (i.e., covering the enterprise zones and the control rings), as well as the enterprise zones separately - including the originally-designated areas as well as the expansions separately - and the 1,000-foot control ring. These are reported for 1992, the first year of the sample. Ideally, we would like pre-treatment comparisons. However, many of the areas in the original zone designations were so designated before 1992, in which case there are no pre-treatment data. As indicated in the first row, enterprise zone employment constitutes about $69 \%$ of total employment in the zones and the control rings, and of this, about $72 \%$ is in the areas originally designated as part of zones. Clearly there is plenty of employment (and also plenty of establishments, as shown in the second row) in the control ring and, of course, in the expansion areas. Perhaps even more informative is the third row, which reports employment density. Although density is higher in the areas designated as enterprise

\footnotetext{
${ }^{35}$ Similar figures for the number of establishments indicate that the establishments in the enterprise zones we study are $6.5 \%$ of the statewide total, and $8.7 \%$ of establishments in the counties in which they are located. In total, we have data on about 124,000 enterprise zone establishments, about 58,000 in control rings, relative to a statewide total of 1.6 million establishments, 1.4 million of which are in the counties with enterprise zones in our study. As for employment, the largest zones (in this case Los Angeles and San Francisco) each account for 1\% or more of the total statewide number of establishments.
} 
zones than the control rings, density is still quite high in the latter. Moreover, density is actually higher in the expansion areas than in the initially-designated areas. The last three rows report establishment size and composition. Average establishment size in the zones and the control rings is quite similar (around 14.5), although slightly higher in the enterprise zone expansion areas than in the originally-designated areas. The same is true of the share of employees in low-wage industries. ${ }^{36}$ The share in manufacturing is somewhat higher in the zone expansion areas, and somewhat lower in the control rings. It is certainly the case that the three types of areas are not identical in terms of these measures; but it would be quite surprising if they were. Nonetheless, there is plenty of employment in the expansion areas and the control rings, and the types of establishments do not appear very different across them. In the empirical analysis, of course, we control for initial or time-invariant differences between the areas by including subzone fixed effects, and in some specifications for different underlying trends in each subzone.

\subsection{The Effects of Enterprise Zones on Jobs and Businesses}

We now turn to estimates of the economic effects of enterprise zones by looking at their effects on employment and the number of business establishments. We have already argued why the employment effect is central. Information on effects on the number of establishments, coupled with information on employment effects, is informative about whether enterprise zones lead to larger establishments (for example, fewer establishments coupled with no effect on employment) or smaller establishments, which is likely related to the question of whether enterprise zones lead to the creation of more new businesses, although we do not explore the latter question directly.

\subsubsection{Descriptive Statistics}

Table 5 presents a simple descriptive analysis. This table treats each subzone-year pair as an observation, as we do in the regression analysis, so that a subzone is classified by year as to whether or not it is in the zone. Reflecting what we regard as the cleanest way to measure the effects of enterprise zones, the control rings are not used in this table, and instead comparisons are only between subzones

\footnotetext{
${ }^{36}$ We ranked industries by average pay based on 2004 data from the Quarterly Census of Employment and Wages, dividing NAICS industry subsectors into three groups, each containing approximately one-third of the workforce.
} 
currently in enterprise zones, and subzones not currently in enterprise zones but which are in enterprise zones in later years. Columns (1) and (2) report unweighted averages of annual percentage changes in employment and the number of establishments, and suggest that for both employment and establishments - but especially employment - the rate of growth was faster after areas were included in enterprise zones.

However, given that there is tremendous variation in size across zones (see Table 3), small zones may contribute large percentage changes but small absolute changes. In columns (3)-(6) we report the same descriptive statistics for below-median and above-median size subzones (in terms of 1992 employment or number of establishments). These columns show that, for employment, the small subzones contribute larger percentage changes in both directions. Moreover, for the larger subzones, which obviously represent a far larger number of jobs or establishments, growth in jobs and the number of establishments was lower in the enterprise zones; the difference is much sharper for job growth.

Weighting the observations by either employment or number of establishments thus gives us estimates that are more representative of what actually happens to jobs or establishments statewide. As reported in columns (7) and (8), when we weight by base-year levels, the weighted estimates are much closer to those using the large subzones. The evidence now suggests that enterprise zones slightly reduced the growth of jobs, with a fairly small relative difference of $0.5 \%$ slower growth in enterprise zones. In contrast, enterprise zones appear to have slightly increased the growth rate in the number of establishments.

\subsubsection{Basic Regression Estimates}

The descriptive statistics reported in Table 5 do not account for other influences on employment and the number of establishments that we want to disentangle from the actual effects of enterprise zones. Regression estimates accounting for these influences are reported in Table 6; these ignore (for now) a number of complications, including the overlap of enterprise zones with areas affected by other geographically-targeted polices. The dependent variable is the log of employment or the number of 
establishments. ${ }^{37}$ All estimates are weighted by 1992 employment levels or numbers of establishments. The control rings are included in columns (1) and (2) but excluded in columns (3) and (4); we view the latter specifications as preferable.

In Panel A, enterprise zone designation shifts the level of employment or number of establishments in the corresponding subzone. The estimates provide no evidence that enterprise zones boost employment as the estimates in columns (1) and (3) are small and statistically insignificant, and actually negative in both cases. With regard to establishments, both estimates indicate that enterprise zones reduce the number of businesses, holding everything else constant. In the preferred specification excluding the control ring the estimate is significant at the 10-percent level (but not based on the bootstrap results). In Panel B we introduce subzone-specific linear time trends. The estimated employment effects are still near zero and not statistically significant, although they are now positive. The estimated effects on number of establishments also become positive, but the effect is small and statistically insignificant in the preferred specification excluding the control rings.

In Panels $\mathrm{C}$ and $\mathrm{D}$ we report the model estimates for the growth rate in the dependent variable. In this case, whether or not we allow subzone-specific trends, there is no evidence of positive effects of enterprise zones on employment; the estimates are small and statistically insignificant. The estimated effects on the number of establishments are always negative, and sometimes statistically significant (based only on the bootstrap results).

Finally, Panels E and F report more flexible models than those in Panels C and D, by allowing enterprise zones to be associated with shifts in the level and growth rate. However, the results are very similar. There is no evidence that enterprise zones affect employment; the estimates are small, statistically insignificant, and negative as often as they are positive. On the other hand, there is again a hint of a negative effect on the number of establishments.

\footnotetext{
37 As indicated in the notes to the table, in the handful of cases where employment (or the number of establishments) was zero (26 observations), we substituted one for zero before taking logs. This can be viewed as perhaps introducing the slightest measurement error, or presuming that the data are not sufficiently accurate to distinguish between zero and one job or establishment in a cell. Regardless, we verified that simply dropping these cases had no impact on the estimates.
} 
Although the specifications with the subzone-specific linear time trends often generate much less precise estimates of the effects of enterprise zones, the inclusion of these time trends has little clear effect on the estimated effects of enterprise zones, suggesting that there is little if any difference in underlying trends between the treatment and control groups. Thus, in what follows we focus on the specifications without the subzone-specific linear time trends, which yield more precise estimates.

As a more flexible way of asking whether enterprise zone designation shifts the level or rate of growth of employment, we re-estimated the baseline model for the employment level (Panel A), with many leads and lags of the enterprise zone dummy variable; these estimates are not reported in a table, but in the figure discussed below. The leads reveal whether enterprise zones have tended to be established in areas that had transitory downturns in employment relative to other areas, in which case our finding of no effect would be strengthened (because the mean reversion would look like a positive treatment effect). Alternatively, if zones are established in areas doing particularly well just before designation, perhaps because such areas have better organized constituents for capturing an enterprise zone, then the estimated effects from the simple model might fail to detect longer-run positive effects of enterprise zone designation on the rate of job growth. Similarly, the many lags allow the data to tell us whether over the longer-term the effects of enterprise zones look different from what is implied by the one-time contemporaneous shift implied by equation (1).

Figure 4 displays the results for the specifications both with and without the control ring. The figure reports the leading (to the left) and lagged (to the right) coefficient estimates, as well as the upper and lower limits of the standard cluster-based 95-percent confidence intervals for each estimate. The figures do not exhibit any evidence indicating that the basic specification obscures more interesting results. For example, there is no evidence of leading effects of enterprise zones because they are either established in places doing particularly well or particularly badly; similarly, there is no evidence that employment increases more further from the date of enterprise zone designation. Thus, the figures give no indication that the simple specifications reported in Table 6 mask any greater richness that might suggest different effects of enterprise zones, whether positive or negative. Instead, the results in Figure 4 cement 
the view that enterprise zones do not affect employment. ${ }^{38}$

The results to this point indicate that enterprise zones have no statistically significant effect on employment. But the statistical power of our test is modest, as the confidence intervals for the estimated employment effects are rather large. For example, in the level specification, the estimates in Panel A, column (3), which exclude the control rings, yield a 95-percent confidence interval of -8.1 to 5.7 percent.

If the enterprise zone program has positive spillovers, encouraging employment growth not only within zone boundaries but just outside zone boundaries as well, then we might find no effect of enterprise zones on employment because we are comparing enterprise zones to immediately neighboring areas. ${ }^{39}$ By using two different control groups - future expansion areas and control rings - we can assess whether spillovers color our results. Future expansion areas are closer to current enterprise zone areas geographically than control rings are, so any spillover effects should be greater in future expansion areas than in control rings. Evidence of positive employment effects when using the control rings but not when using only the future expansion areas would suggest that zones create positive spillover effects in neighboring areas. However, since our results with and without control rings are similar, we discount the possibility of positive spillover effects. Similarly, had we found evidence of a positive effect using the larger (2,500-foot) control rings, we might have reached this conclusion. However, as discussed below, the results are essentially unchanged using the larger control rings.

Perhaps a more likely scenario, especially given our research design, is that there are negative spillover effects, with enterprise zones pulling jobs and businesses away from nearby areas. Given that our control areas are geographically close to our treatment areas, it might be fairly easy for businesses to move to take advantage of enterprise zone incentives (without, for example, inconveniencing their workforce), or for similar results to occur via the location decisions of new businesses. The similarity of

\footnotetext{
38 The specifications in Panels A and B of Table 6 might be more likely to detect short-run shifts in outcomes associated with enterprise zones, while the specifications in Panels C and D of Table 6 would more likely capture longer-run effects. The failure to find evidence of employment effects of enterprise zone effects in either type of specification is consistent with findings - reported in Figure 4 - that adding explicit lagged (or leading) enterprise zone variables to the specification for levels led to no evidence of employment effects.

${ }^{39}$ Spillovers could stem from a number of sources, including increased retail "traffic," rising incomes of nearby residents, and changes in infrastructure.
} 
results with and without control rings also undermines this possibility. Moreover, such negative spillovers would tend to produce evidence that enterprise zones do encourage job growth relative to control areas. Thus, if there were negative spillovers, our conclusion that there are not positive employment effects would only be reinforced.

Although the evidence on number of establishments is weak, one possible interpretation of a decline in the establishment count coupled with no change in employment - which implies that establishments are becoming larger - is that there are fixed costs to taking advantage of enterprise zone benefits, and large establishments (or firms) are therefore more likely to find enterprise zone benefits attractive. If this interpretation is valid, it suggests that enterprise zone policies do not particularly favor and may even adversely affect entrepreneurship in the form of small business creation. ${ }^{40}$

\subsubsection{Accounting for Other Local Economic Policies}

We next turn to the analysis where we account for the overlap between state enterprise zones and redevelopment areas or federal zones. Table 7 reports the share of enterprise zone employment that is in either redevelopment areas or federal zones, in the last year of our sample. Clearly both redevelopment areas and federal zones sometimes cover a wide swath of enterprise zones.

The regression models are now expanded to include a dummy variable for redevelopment areas or federal zones, and an interaction for regions that are in both enterprise zones and one of these other areas. As reported in Table 8, in all of the estimations the estimated effects of enterprise zones in areas that do not overlap with redevelopment areas (columns (1) and (2)) or federal zones (columns (3) and (4)) which are reported in the first row of each panel - are small, statistically insignificant, and generally negative. This is true for the effects on both employment and the number of establishments. The effects of enterprise zones that overlap with these other areas comes from the sum of these estimates plus the

\footnotetext{
40 There is a long-standing debate on whether small businesses create more jobs, on net, than large businesses. Neumark et al. (2008) provide recent evidence on this question using the NETS data, pointing to a higher net job creation rate from small businesses.
} 
estimated interactions between enterprise zone and either redevelopment areas or federal zones. ${ }^{41}$ As reported in the fourth row of each panel, these estimates are almost always negative, and based on the bootstrap results they are never statistically significant. ${ }^{42}$ There is also no evidence of significant differences between the effects of enterprise zones that are or are not part of redevelopment areas or federal zones (the interactions, reported in the third row of each panel). The main conclusion is that there is no evidence that enterprise zones have positive employment effects, whether or not they are combined with these other local policies. ${ }^{43,44}$

\subsubsection{Effects on the Composition of Employment}

The results to this point suggest that enterprise zones do not affect employment growth. However, using a criterion of overall job growth may be inappropriate. After all, one goal of enterprise zones is to help create jobs among those who are economically disadvantaged and likely to be low-skilled. In addition, some of the enterprise zone benefits targeted on machinery and property are most likely to benefit manufacturing enterprises. Thus, it is possible that enterprise zones do not affect overall employment growth, but nonetheless affect the composition of employment growth.

The NETS data do not permit us to say anything about the characteristics of workers employed by a business establishment. Nonetheless, we can ask whether there is a shift toward lower-paying industries. We might not normally think of this as a good outcome, but in this case it could reflect increased hiring of

\footnotetext{
${ }^{41}$ Negative interactions could arise if, for instance, different programs offer duplicative benefits; in this case, the marginal effect of one program would be lower for an area covered by another program than for an area not covered by another program.

$42 \mathrm{We}$ actually did the bootstrap inference for these effects by respecifying the model so that the effect of enterprise zones in either redevelopment areas or federal zones was captured in a single coefficient.

43 There is also no evidence of positive effects of redevelopment areas or federal zones. We do not emphasize these findings, however, as our research was not designed to assess the effects of these areas in the most definitive way, but instead simply to distinguish between different "parts" of enterprise zone areas - that do and do not overlap with redevelopment areas or federal zones. In particular, the comparison groups are either other parts of enterprise zones or the rings around them, which are not necessarily the best comparison groups for estimating the effects of redevelopment areas or federal zones. In addition, the mapping of redevelopment areas is not as accurate as the mapping of enterprise zones. And finally, the incentives are not uniform across the federal zones (U.S. General Accounting Office, 2004; Busso and Kline, 2007).

44 There are also a few other state programs focused on specific areas, including: the Los Angeles Revitalization Zone (LARZ), Local Agency Military Base Recovery Areas, the Tulare Targeted Tax Area, and Manufacturing Enhancement Areas (in Imperial County). We address potential problems from overlap between the LARZ and the Los Angeles and Long Beach zones below.
} 
less-skilled workers. On the other hand, it could be that the shift to less-skilled workers occurs within industries, which we would not observe. It is straightforward in the NETS to ask whether enterprise zones are associated with shifts in the share of employment in manufacturing.

The results for employment in low-wage industries, reported in the first two columns of Table 9, do not provide any indication that enterprise zones shift employment towards (or away from) low-wage industries. Nearly all of the estimated compositional effects are small and statistically insignificant, and the only exceptions are the negative and significant (but still small) estimates for the specifications in Panels $\mathrm{E}$ and $\mathrm{F}$, for the effect of enterprise zones on the level of employment. The estimates in columns (3) and (4) suggest that there is a positive and statistically significant effect on the growth rate of the share of employment in manufacturing, when the control rings are excluded. However, the effects on the growth rate in Panels $\mathrm{C}$ and $\mathrm{E}$ are not significant based on the bootstrap results, and there is no effect in any of the levels specifications. Thus, there is some evidence, although it is weak, that enterprise zones may shift employment towards manufacturing.

\subsubsection{Sensitivity Analyses}

Finally, we report on a number of sensitivity analyses. The first set of these focuses on whether our conclusions are sensitive to issues regarding the mapping, or "measurement," of the enterprise zones or the control rings. In Table 10, row 1 reports the baseline estimates from Table 6 . Then rows 2-4 present estimates for the variations in how we define the enterprise zones or control rings. First, we use a 2,500foot control ring instead of a 1,000-foot control ring. This results in little change, although in one case (column (6)) there is stronger evidence of a negative effect on the number of establishments. Second, we revert to the 1,000-foot control ring, but include questionable streets that are in the interior of the zones but are not explicitly listed as belonging to them. This has virtually no impact on the estimates. And third, we revert to the 1,000-foot control ring and exclude questionable streets, but we also exclude a 100-foot buffer (in any direction) from the enterprise zone boundary, to exclude observations that might be more likely to be incorrectly classified as in or out of the zone. This, too, has no substantive effect on the estimates. 
Next, we consider alternative weighting schemes. In row 5 we report estimates in which we do not weight the observations. A somewhat different weighting issue arises because our unit of observation is the subzone-year pair, which implies that if a particular zone had a lot of little expansions as opposed to a smaller number of relatively larger expansions, that zone contributes more observations. However, we may not want the estimates to be weighted towards zones with more expansions. ${ }^{45}$ One way to make the estimates representative of zones rather than subzones is to weight the observations inversely by the number of subzones. Estimates with this weighting are reported in row 6 of Table 10. These estimates with different (or no) weighting are sometimes slightly different in that some specifications provide evidence of positive effects of enterprise zones on the growth rate of employment. In addition, these estimates point to if anything weaker evidence of declines in the number of establishments. Nonetheless, the weighting used in the main tables is our preferred specification, because it makes the estimates representative of what happens to workers, treating each observed designation of an area as eligible for enterprise zone benefits as an "experiment." Moreover, the estimates without weighting or with this alternative weighting, and excluding the control rings, are much less precise and in some cases (e.g., column (7)) implausibly large. ${ }^{46}$

Because Los Angeles is so large (and perhaps because it has so many expansions), it may have a large influence on the estimates. We therefore, in the row 7 of Table 10, report results excluding Los Angeles. ${ }^{47}$ For the specifications with the control rings, in this case we find positive employment effects. However, for the specification without the control rings, which we regard as more reliable, we only find a positive effect of enterprise zones for the growth rate specification. More substantively, as we noted earlier, there is the potential for overlap between the Los Angeles Revitalization Zone (LARZ) and the Los Angeles and Long Beach enterprise zones. The LARZ offers benefits that are very similar to those of

\footnotetext{
45 The weighting by base-year employment or establishment levels offsets this to some extent, since when a zone is divided into more subzones because of a greater number of expansions, all else the same, each subzone gets a lower base-year weight.

${ }^{46}$ Recall that we first raised the issue of weighting with respect to Table 5. There, we saw that, in the raw data, the percentage growth in subzones after they became part of the enterprise zone was higher. Here, in contrast, we are reporting the estimates of highly-saturated regression models.

${ }^{47}$ In addition, recall that mapping enterprise zone boundaries for Los Angeles was more difficult.
} 
the state enterprise zone program (Assembly Jobs, Economic Development, and the Economy Committee, 2006). Because of the potential overlap and similar benefits, and given that the LARZ started in 1992, failure to account for overlap between the LARZ and subzones into which the Los Angeles or Long Beach zones expanded after 1992 can lead to misclassification of the treatment and control groups. Consequently, we excluded the Census tracts and cities covered by the LARZ, ${ }^{48}$ and re-estimated our models. The results, reported in row 8 of Table 10, yield results that are very robust relative to the baseline estimates in the top row, indicating that the overlap between the LARZ and the Los Angeles and Long Beach enterprise zones does not affect our results. ${ }^{49}$

Finally, we consider two issues related to the timing of enterprise zone designation. First, we ask whether the effects of initial enterprise zone designation differ from the effects of subsequent zone expansions. ${ }^{50}$ Since initial designation results from a different process than subsequent expansions, the effects could differ. The specification in row 9 of Table 10 shows that the effect of initial designations is not significantly different from the overall enterprise zone effect. ${ }^{51}$ Second, we ask whether enterprise zones became more effective at creating jobs starting in 1997, when the pool of workers eligible for the hiring credit areas expanded to include those in TEA's. As shown in row 10 of the table, there is no evidence of this, with the exception of one specification. And although not shown in the table, the differences between the effects in the two sub-periods were never statistically significant.

Overall, then, the earlier analysis plus all of our sensitivity analyses establish that our estimates indicating that state enterprise zones in California do not boost employment growth is generally robust.

\footnotetext{
48 See http://www.hcd.ca.gov/fa/cdbg/ez/larz/ (viewed November 10, 2008).

49 This may reflect the fact that the overlap is not extensive. Using the census tracts that include the LARZ, which encompass more than the actual streets covered, as of 2004 only 5\% of Los Angeles enterprise zone employment and $7.7 \%$ of Long Beach enterprise zone employment was in the LARZ. These percentages are considerably lower than those covered by redevelopment areas or federal zones, as reported in Table 7.

50 The specification includes the enterprise zone dummy variable as well as an interaction of this dummy variable with a corresponding dummy variable for the initially-designated areas only; the coefficient of the interaction measures the difference between the effect in initially-designated areas and expansion areas.

${ }^{51} \mathrm{We}$ report only the model with control rings. The initial-designation estimates are identified from five zones that were designated after 1992 (and before 2004). Only two of these - Oakland and Santa Ana - had subsequent expansions (which serve as the control group when control rings are excluded), and Oakland's expansion was very small in terms of employment and therefore quite imprecise as a control group for the initial Oakland designation. Omitting control rings would mean identifying the initial designation effect essentially only from Santa Ana.
} 
The estimates for the effects of enterprise zones on the number of establishments is perhaps less robust, with some indication that enterprise zones may reduce the number of establishments.

\section{Discussion and Conclusions}

Our analysis of California's enterprise zone program cannot reject the hypothesis that the program fails to increase employment. We arrived at this conclusion after drawing precise enterprise zone boundaries digitally, mapping nearly all businesses in the state, accounting for other geographicallytargeted policies, and comparing employment growth in enterprise zones with carefully considered control areas. We do not assess the effect of the program on unemployment or poverty, but it is hard to see how these outcomes could improve in the absence of a positive effect on employment. ${ }^{52}$

At the same time, we find some evidence that enterprise zones reduce the number of establishments, which coupled with lack of an employment effect suggests that establishments are growing in size. Increasing establishment size is consistent with survey respondents' comments that smaller businesses find it less worthwhile than larger businesses do to claim enterprise zone benefits because of the administrative burden. ${ }^{53}$ Another possibility is that increased prices for land relative to other inputs lead employers to substitute towards other inputs including labor.

The lack of a significant effect on employment may seem surprising in light of the program's incentives. In fact, however, economic theory provides some possible explanations for the absence of an employment effect or at least a weak effect. First, as noted earlier, the strongest incentive offered by the enterprise zone program is for hiring disadvantaged workers. If there are opportunities to substitute lowskilled for higher-skilled labor, however, this incentive may induce a fair amount of "labor-labor" substitution, with weaker effects on employment overall. At the same time, this kind of substitution might

\footnotetext{
52 As noted earlier, if enterprise zones have beneficial spillover effects onto other nearby areas, then benefits of the program estimated from comparisons of areas inside the zone to areas outside the zone may be understated. Nonetheless, our results would still imply that enterprise zones do not differentially benefit the areas they target. Although we cannot rule out this possibility, we regard it as unlikely because our estimated effects were not sensitive to using control groups that extended increasingly further from the enterprise zone itself.

${ }^{53}$ See Kolko and Neumark (2010). This is also consistent with evidence from a HUD survey indicating that large firms used federal enterprise zone tax credits, wage subsidies, and capital write-offs much more intensively than small firms (Hebert et al., 2001).
} 
still lead to beneficial shifts in the composition of employment to the extent that the program is intended to improve job opportunities for the disadvantaged. Our ability to assess whether there is labor-labor substitution is limited by the available data. All we can do is ask whether enterprise zones shift employment toward low-wage industries that might be more likely to employ these workers, and we find no such effect. ${ }^{54}$ In addition, our evidence suggests that there is no overall increase in employment, and although in theory it is possible to have labor-labor substitution and yet no increase in employment, this can occur only under special conditions which we regard as unlikely to hold. ${ }^{55}$

The second possible explanation suggested by economic theory is that some of the enterprise zone benefits targeting machinery and property could lead to substitution away from labor and towards other inputs; depending on the magnitude of scale and substitution effects of lower prices for other inputs, the overall employment effect could be positive or negative. We find it less plausible that the enterprise zone program leads to substitution away from labor and towards other non-labor inputs, given the generosity of the hiring credit - although admittedly we do not know the magnitudes of all of the relevant elasticities. ${ }^{56}$

One argument that we do not think is the right explanation is that the incentive effect of the program is weak. If we simply divide the cost of the program by the number of jobs in enterprise zones,

54 A related possible beneficial effect of the program is increasing incomes of affected workers, owing to the tax credit. In the absence of employment effects, however, the wage increases only if labor supply is perfectly inelastic, which does not seem plausible. The relevant elasticity is for the extensive margin of labor supply - that is, entry into the labor market in response to a higher wage. There is ample evidence of elastic labor supply on this dimension. See, for example, Juhn (1992). At the same time, Bostic and Prohofsky (2006) find positive wage effects in the very short-run (1-2 years) for low-wage affected workers (a non-representative sample of workers for whom employers claimed an enterprise-zone-specific hiring tax credit).

55 Suppose there are three inputs - unskilled labor, skilled labor, and capital. The hiring credit reduces the cost of unskilled labor. Assuming that the two types of labor are substitutes, the hiring credit induces substitution from skilled to unskilled labor. If unskilled labor and capital are also substitutes, the credit also induces substitution from capital to unskilled labor. These substitutions, in turn, lower the cost of production leading to a positive scale effect, so total employment increases. However, if capital and unskilled labor are complements, then the firm may substitute sufficiently strongly toward capital as well that skilled labor and total employment declines. Research on production functions suggests that, if anything, it is capital and skilled labor that is complementary, making it even less likely that the hiring credit could increase unskilled labor without increasing employment. (The same issue comes up in the context of minimum wages, which increase the price of unskilled labor; see Neumark and Wascher, 2008, Chapter 3.)

${ }^{56}$ Lynch and Zax (2008) discuss substitution between labor and other inputs. They suggest that one interpretation of their findings that Colorado's enterprise zone benefits do not boost employment at existing establishments is that there is substitution towards capital that offsets any effect of reduced labor costs. It is the case that the Colorado enterprise program has relatively strong capital subsidies and weak labor subsidies, in contrast to California; Lynch and Zax argue that the most valuable enterprise zone incentive in Colorado is a $3 \%$ investment tax credit, while the hiring tax credit is simply $\$ 500$ for each new employee. 
one might get this impression; using the 2005 spending figure of about $\$ 330$ million on hiring credits and sales and use tax credits (California Franchise Tax Board, 2006), and dividing by enterprise zone employment of roughly 1.4 million, yields an estimate of about $\$ 240$ per worker. However, what is relevant is the effect of program subsidies at the margin; clearly a fairly large share of enterprise zone employment would occur regardless of the program. At any rate, if the program incentives are too weak to affect behavior, then it remains difficult to justify the program's costs. A second argument that also does not explain the absence of an employment effect is that capitalization of enterprise zone benefits into land values eliminates the incentive effects of the enterprise zone benefits. Even if land values rise, reductions in the relative cost of labor owing to the hiring credit still imply that employers will substitute toward labor. And indeed increased land values may reflect an outward shift in the demand for land against an upward-sloping supply of land available for businesses. ${ }^{57}$

We have argued that the data and strategies we use to estimate the effects of enterprise zones meet many of the challenges that arise in the literature on enterprise zone evaluation. As it turns out, though, our findings are consistent with much of the literature, in particular with more the recent and what we regard as the more compelling studies. We already noted that many studies conclude that enterprise zones are ineffective at creating jobs, consistent with our conclusions. If we use the confidence intervals for our estimates to ask whether our approach "rules out" estimated magnitudes in the existing literature, again we find broad consistency, although the results for other states or federal programs may vary because of differences in incentives or other interventions. For example, the specification in Panel A of Table 6, column (3), yields an estimate of a 1.2 percent reduction in employment, with the 95-percent confidence interval ranging from an effect of -8.1 percent to 5.7 percent; the 95 -percent confidence interval for the effect on the annual growth rate (Panel C) is -2.2 percent to 4.0 percent. Busso and Kline (2007, Table 10) report effects on the employment rate in a five-year interval, from their preferred specification, implying an annual growth rate that is higher by 0.6 percent, within this confidence interval. O'Keefe

\footnotetext{
${ }^{57}$ Landers (2006) suggests that this capitalization occurs to some extent in industrial and commercial property values, with the magnitude of the effect depending on other factors such as the supply elasticity of land.
} 
(2004) estimates that enterprise zone designation boosts employment growth by 3 percent per year for the first six years of enterprise zone designation - an estimate that is also within our confidence interval; on the other hand, she finds that this effect does not persist after six years, with the results pointing to negative but insignificant effects in years eight through 13. Elvery (2009) finds insignificant negative employment effects; for California his estimates for men and women combined are in the -0.1 to -0.6 range, quite consistent with ours. Ham et al. (2009) also find no effect of California' enterprise zones on employment (p. 17) - a trivially small and insignificant positive effect of 31 additional employees attributable to designation (they do not report the means with which to calculate the implied percentage increase). ${ }^{58}$ The results in Billings (2007) are not easily translatable, but if we use his estimates for existing establishments (Table 3, row 1) they suggest effects on the level of employment of approximately 1.3 to 2.1 percent, ${ }^{59}$ which are within our confidence interval. Moreover, even researchers who find some positive and significant point estimates of the effects of state programs tend to downplay the strength of the results. As already noted, O'Keefe (2004) points out that the positive job creation effects do not last; and Billings (2007) concludes that his results "weakly support the idea that ... job creation tax credits positively influence ... job creation" (p. 25).

We cannot necessarily generalize conclusions regarding the absence of job creation effects of California's enterprise zone program to state enterprise programs elsewhere, because programs are not the same everywhere, although they often have a similar set of incentives. ${ }^{60}$ The generalization is probably least valid with respect to the federal programs, which also entail other interventions including large block grants aimed at poverty reduction, as well as loans for improvements in local infrastructure, and for which the existing evidence seems to point more strongly to beneficial effects (Busso and Kline, 2007). ${ }^{61}$

\footnotetext{
58 Other results in this study are curious. First, the only state in which enterprise zones have detectable employment effects is Ohio, although in that state the hiring credit is trivial. Second, for California, despite finding no employment effects, the study finds significant and positive effects on the fraction of households with wage and salary income. Conversely, in Ohio, despite the apparent strong employment effects, the study finds no effect on this fraction.

${ }^{59}$ We use the sample means for all establishments from his Table 1, for the corresponding columns.

60 See, e.g., National Conference of State Legislatures (2005).

${ }^{61}$ Ham et al. (2009) also find positive employment effects of federal zones.
} 
Indeed, if the beneficial effects of federal programs hold up in further research, then the contrast with apparently ineffective state programs raises two questions. First, do these other interventions included in the federal programs account for the apparent differences in the effects of federal versus state programs, suggesting that states seeking to improve the effectiveness of their programs should incorporate these elements of federal programs? And second, aside from these other interventions, are the federal tax incentives that parallel those offered by state enterprise programs ineffective, or do they perhaps interact to enhance the effects of the federal block grants and infrastructure loans? 


\section{Appendix A: Geocoding the NETS}

Although the NETS contains the street address of each business establishment, we needed to geocode the exact locations of these establishments to be able to use our GIS maps of enterprise zones (and other targeted areas) to identify whether establishments are inside or outside the zones. ${ }^{62}$ "Geocoding" is the conversion of street addresses or other designators to latitude-longitude coordinates, which is common language that allows geographic information from different sources to be combined.

We geocoded using the U.S. StreetMap Premium data, published by TeleAtlas. We matched NETS addresses with the street map using street names, street numbers, and zip codes, in ArcGIS. We performed this matching process at a high "spelling sensitivity" option of 80 and at a low option of $40 .{ }^{63}$ For each round of matching, this process returns a "match score" for each address on a 0-100 scale, reflecting the likelihood that the NETS address matched its correct analog in the street map file. With a high spelling sensitivity, more addresses fail to have a reasonable match (a match score above 60), but more have a very high match score. Thus, we used both rounds of matching; we chose the result with the higher match score and treated match scores below 60 as failed matches that we exclude from subsequent analysis. With these procedures and a few other refinements that added a modest number of matches, of 21 million establishment-year observations, $95.3 \%$ were successfully geocoded. ${ }^{64}$ Among these, $96 \%$ had a match score of 80 or higher. Establishments were less likely to be geocoded if they had over 1,000 employees, and were in agriculture, utilities, or public administration, or located in rural counties.

${ }^{62}$ Latitude and longitude information provided in the NETS is not sufficiently precise to identify side of street. In addition, the NETS reports these only for the last observation on each establishment, and often uses the centroid of the zip code rather than to the exact street address. Thus, we entirely redid the geocoding.

63 The spelling sensitivity controls how much variation in spelling the software allows when it searches for likely match candidates; the higher the value, the more restricted the number of candidates.

${ }^{64} \mathrm{We}$ pursued a number of refinements. First, because some establishments have non-standard addresses, like retail centers or landmark names (rather than street addresses), we did a second round of geocoding with an address locator consisting of these named features instead of street names. We were able to geocode (or improve the match for) an additional 2,000 or so establishments this way. Second, we examined cases where establishments were not successfully geocoded for up to a maximum of four consecutive years but were successfully geocoded to the same address (i.e., they had not relocated) both before and after the year(s) they were not geocoded. We replaced the ungeocoded establishment-years with the latitude and longitude from the successfully geocoded years, on the assumption that the ungeocoded years were due to errors or misspellings rather than establishments moving from an identifiable location to an ungeocodable location and then back to the same identifiable location. This "filling-in" process geocoded an additional 15,000 or so observations. Finally, we manually geocoded a few hundred observations, primarily establishments in airports and military bases. 


\section{References}

Assembly Jobs, Economic Development, and the Economy Committee, "20 Years of California Enterprise Zones: A Review and Prospectus,” Sacramento, California, April 12, 2006.

Billings, Stephen, "Do Enterprise Zones Work? An Analysis at the Borders," Public Finance Review, Vol. 37, No. 1, 2009, pp. 68-93.

Boarnet, Marlon, "Enterprise Zones and Job Creation: Linking Evaluation and Practice," Economic Development Quarterly, Vol. 15, No. 3, 2001, pp. 242-254.

Boarnet, Marlon G., and William T. Bogart, "Enterprise Zones and Employment: Evidence from New Jersey," Journal of Urban Economics, Vol. 40, No. 2, 1996, pp. 198-215.

Bondonio, Daniele, and John Engberg, "Enterprise Zones and Local Employment: Evidence from the States’ Programs,” Regional Science \& Urban Economics, Vol. 30, No. 5, 2000, pp. 519-549.

Bondonio, Daniele, and Robert T. Greenbaum, "Do Local Tax Incentives Affect Economic Growth? What Mean Impacts Miss in the Analysis of Enterprise Zone Policies," Regional Science \& Urban Economics, Vol. 37, No. 1, 2007, pp. 121-36.

Bostic, Raphael, and Allen Prohofsky, "Enterprise Zones and Individual Welfare: A Case Study of California," Journal of Regional Science, Vol. 46, No. 2, 2006, pp. 175-203.

Burkhauser, Richard V., and Kosali I. Simon, "Who Gets What from Employment Pay or Play Mandates?" Risk Management and Insurance Review, Vol. 11, No. 1, 2008, pp. 75-102.

Busso, Matias, and Patrick Kline, "Do Local Economic Development Programs Work? Evidence From the Federal Empowerment Zone Program," unpublished manuscript, 2007.

California Budget Project, California's Enterprise Zones Miss the Mark, Sacramento, California, April 2006.

California Franchise Tax Board, Annual Report 2006, http://www.ftb.ca.gov/aboutftb/annrpt/2006/2006AR.pdf, viewed August 26, 2008.

California Redevelopment Association, "What Can Redevelopment Do?," http://www.calredevelop.org/AM/Template.cfm?Section=Home\&TEMPLATE=/CM/ContentDisplay.cfm \&CONTENTID=1705, viewed August 26, 2008.

Cameron, A. Colin, Jonah B. Gelbach, and Douglas L. Miller, "Bootstrap-Based Improvements for Inference with Clustered Errors," Review of Economics and Statistics, Vol. 90, No. 3, 2008, pp. 414-27.

Dabney, Dan Y., "Do Enterprise Zone Incentives Affect Business Location Decisions?” Economic Development Quarterly, Vol. 5, No. 4, 1991, pp. 325-334.

Dardia, Michael, Subsidizing Redevelopment in California, San Francisco, Public Policy Institute of California, 1998.

Dowall, David E., “An Evaluation of California's Enterprise Zone Programs," Economic Development Quarterly, Vol. 10, No. 4, 1996, pp. 352-368.

Elvery, Joel, "The Impact of Enterprise Zones on Residential Employment: An Evaluation of the Enterprise Zone Programs of California and Florida," Economic Development Quarterly, Vol. 23, No. 1, 2009, pp. 44-59.

Engberg, John B., and Robert T. Greenbaum, "State Enterprise Zones and Local Housing Markets," Journal of Housing Research, Vol. 10, No. 2, 1999, pp. 163-87.

Greenbaum, Robert, and John Engberg, "The Impact of State Enterprise Zones on Urban Manufacturing 
Establishments," Journal of Policy Analysis and Management, Vol. 23, No. 2, 2004, pp. 315-339.

Ham, John C., Ayse Imrohoroglu, and Charles Swenson, "Government Programs Can Improve Local Labor Markets: Evidence from State Enterprise Zones, Federal Empowerment Zones and Federal Enterprise Communities," unpublished paper, 2009.

Hanson, Andrew, "Local Employment, Poverty, and Property Value Effects of Geographically-Targeted Tax Incentives: An Instrumental Variables Approach," Regional Science and Urban Economics, 2009, in press.

Hebert, Scott, Avis Vidal, Greg Mills, Franklin James, and Debbie Gruenstein, "Interim Assessment of the Empowerment Zones and Enterprise Communities (EZ/EC) Program: A Progress Report." Office of Policy Development and Research, 2001, http://www.huduser.org/Publications/pdf/ezec_report.pdf, viewed August 28, 2008.

Juhn, Chinhui, "Decline of Male Labor Market Participation: The Role of Declining Market Opportunities," Quarterly Journal of Economics, Vol. 107, No. 1, 1992, pp. 79-121.

Kolko, Jed, and David Neumark, "Do Some Enterprise Zones Create Jobs?" Journal of Policy Analysis and Management, Vol. 29, No. 1, 2010, pp. 5-38.

Landers, Jim, "Why Don't Enterprise Zones Work? Estimates of the Extent that EZ Benefits are Capitalized into Property Values," The Journal of Regional Analysis \& Policy, Vol. 36, No. 1, 2006, pp. 15-30.

Lynch, Devon, and Jeffrey S. Zax, "Incidence and Substitution in Enterprise Zone Programs," unpublished manuscript, 2008.

National Conference of State Legislatures, "Enterprise Zones: Development for Distressed Communities," Legisbrief, Vol. 13, No. 38, 2005.

Neumark, David, and Jed Kolko, "Do Enterprise Zones Create Jobs? Evidence from California's Enterprise Zone Program,” NBER Working Paper No. 14530, 2008.

Neumark, David, Brandon Wall, and Junfu Zhang, "Do Small Businesses Create More Jobs? New Evidence for the United States from the National Establishment Time Series." IZA Discussion Paper No. 3888, 2008.

Neumark, David, and William Wascher. 2008. Minimum Wages. Cambridge, MA: MIT Press.

Neumark, David, Junfu Zhang, and Brandon Wall, "Employment Dynamics and Business Relocation: New Evidence from the National Establishment Time Series," Research in Labor Economics, Vol. 26, 2007, pp. 39-84.

O'Keefe, Suzanne, "Job Creation in California's Enterprise Zones: A Comparison Using a Propensity Score Matching Model," Journal of Urban Economics, Vol. 55, No. 1, 2004, pp. 131-150.

Papke, Leslie E., "Tax Policy and Urban Development: Evidence from the Indiana Enterprise Zone Program," Journal of Public Economics, Vol. 54, No. 1, 1994, pp. 37-49.

Papke, Leslie E., "What Do We Know About Enterprise Zones?" Tax Policy and the Economy, Vol. 7, 1993, pp. 37-72.

Peters, Alan H., and Peter S. Fisher, State Enterprise Zone Programs: Have They Worked?, W.E. Upjohn Institute for Employment Research, Kalamazoo, Michigan, 2002.

U.S. Department of Housing and Urban Development, "Tax Incentives Guide for Businesses in the Renewal Communities, Empowerment Zones and Enterprise Communities,” Washington, D.C., 2003.

U.S. General Accounting Office, "Community Development: Federal Revitalization Programs are Being 
Implemented, but Data on Use of Tax Benefits are Limited," Washington, D.C., 2004, http://www.gao.gov/new.items/d04306.pdf, viewed October 1, 2008.

Wilder, Margaret, and Barry Rubin, "Rhetoric Versus Reality: A Review of Studies on State Enterprise Zone Programs," Journal of the American Planning Association, Vol. 62, No. 4, 1996, pp. 472-492. 
Figure 1: Enterprise Zone Streets for San Diego (Barrio Logan), by Year (1987 designation in grey; 1991 and 1998 expansions in black)

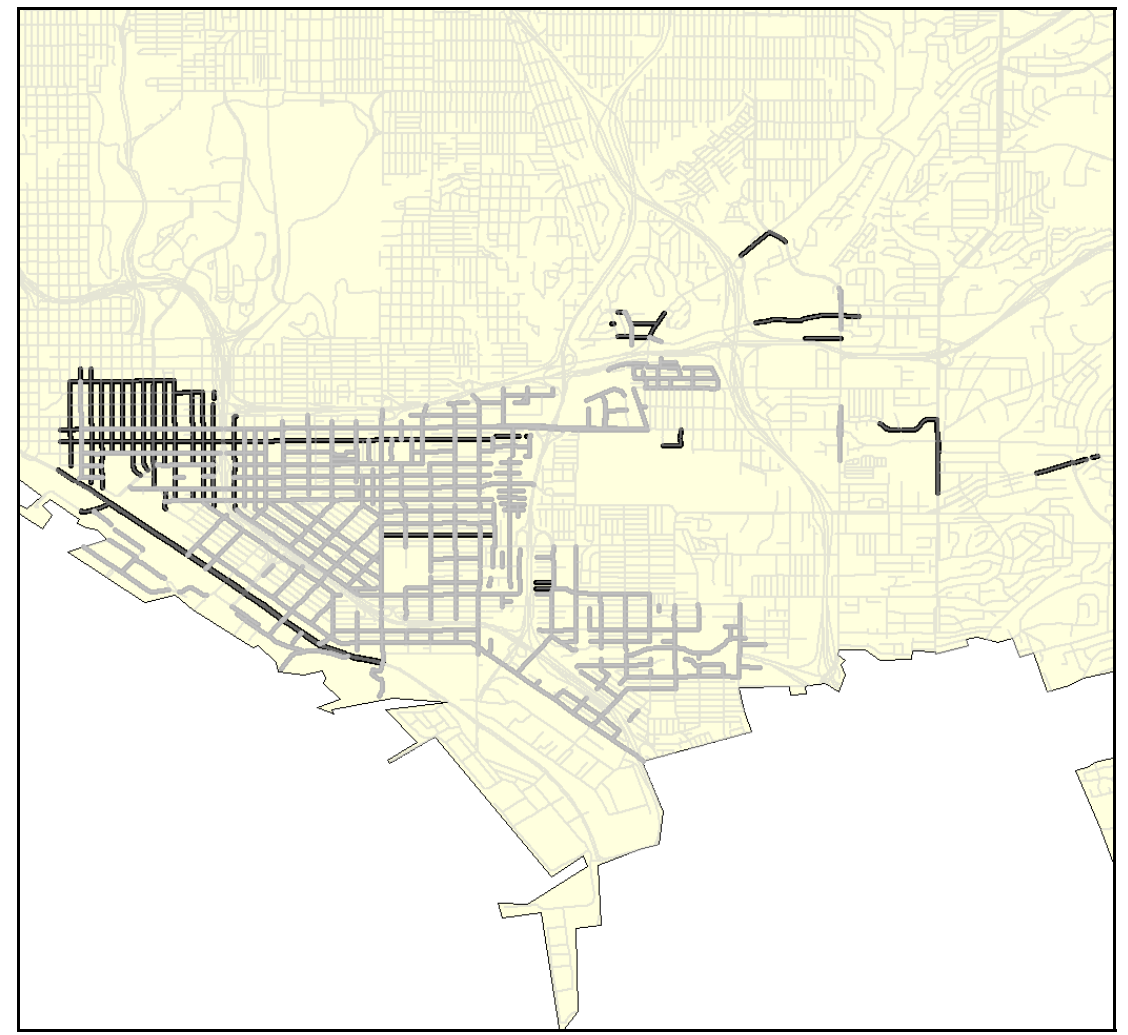


Figure 2: Santa Ana Redevelopment Areas (grey regions), Federal Zones (thick black outline), and State Enterprise Zone Streets (thin grey lines) as of 2004

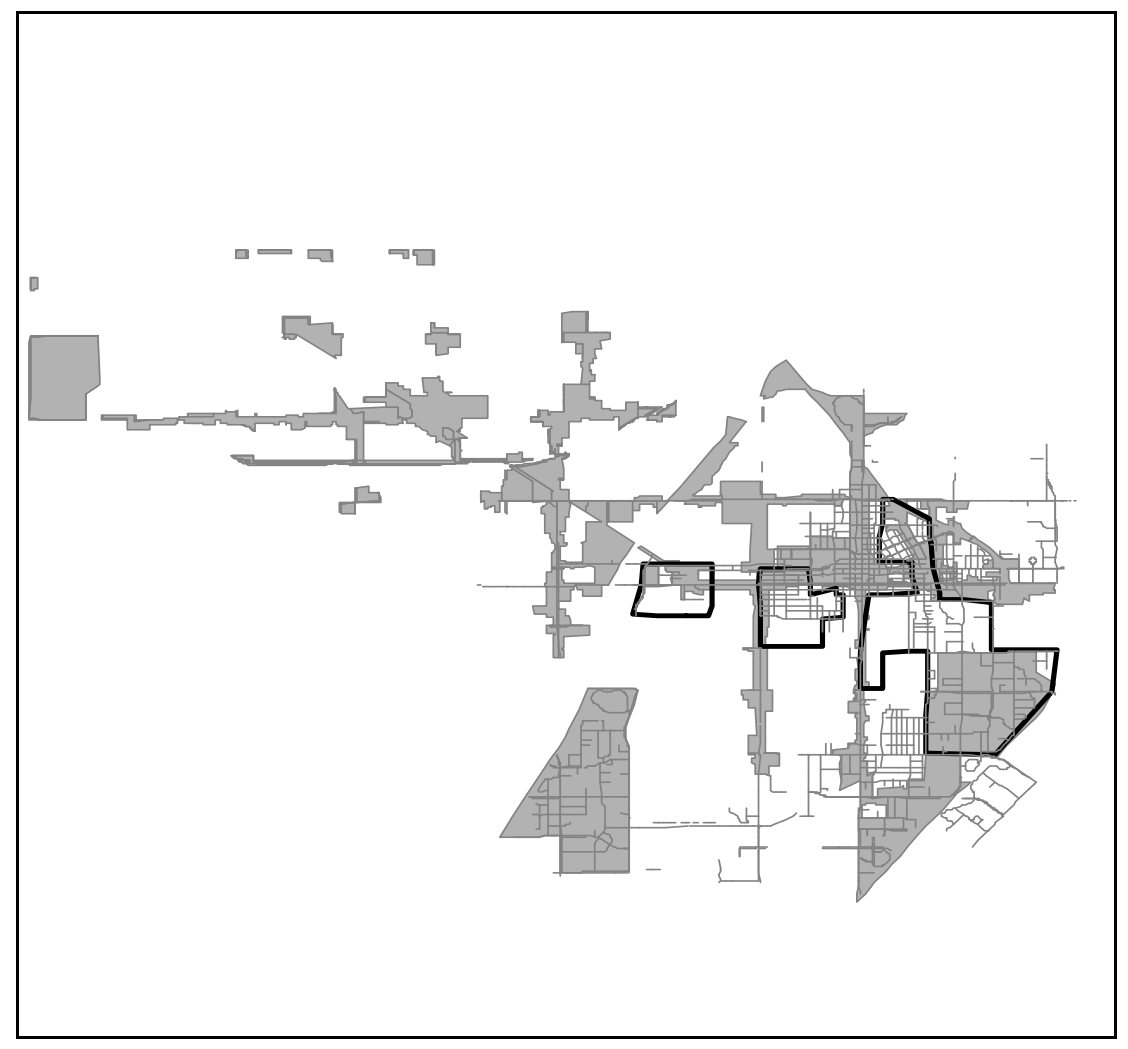


Figure 3: Santa Ana Enterprise Zone, Initial 1993 Designation (thick black lines), 1994 Expansion (light grey lines), and Control Ring (dark grey outer envelope)

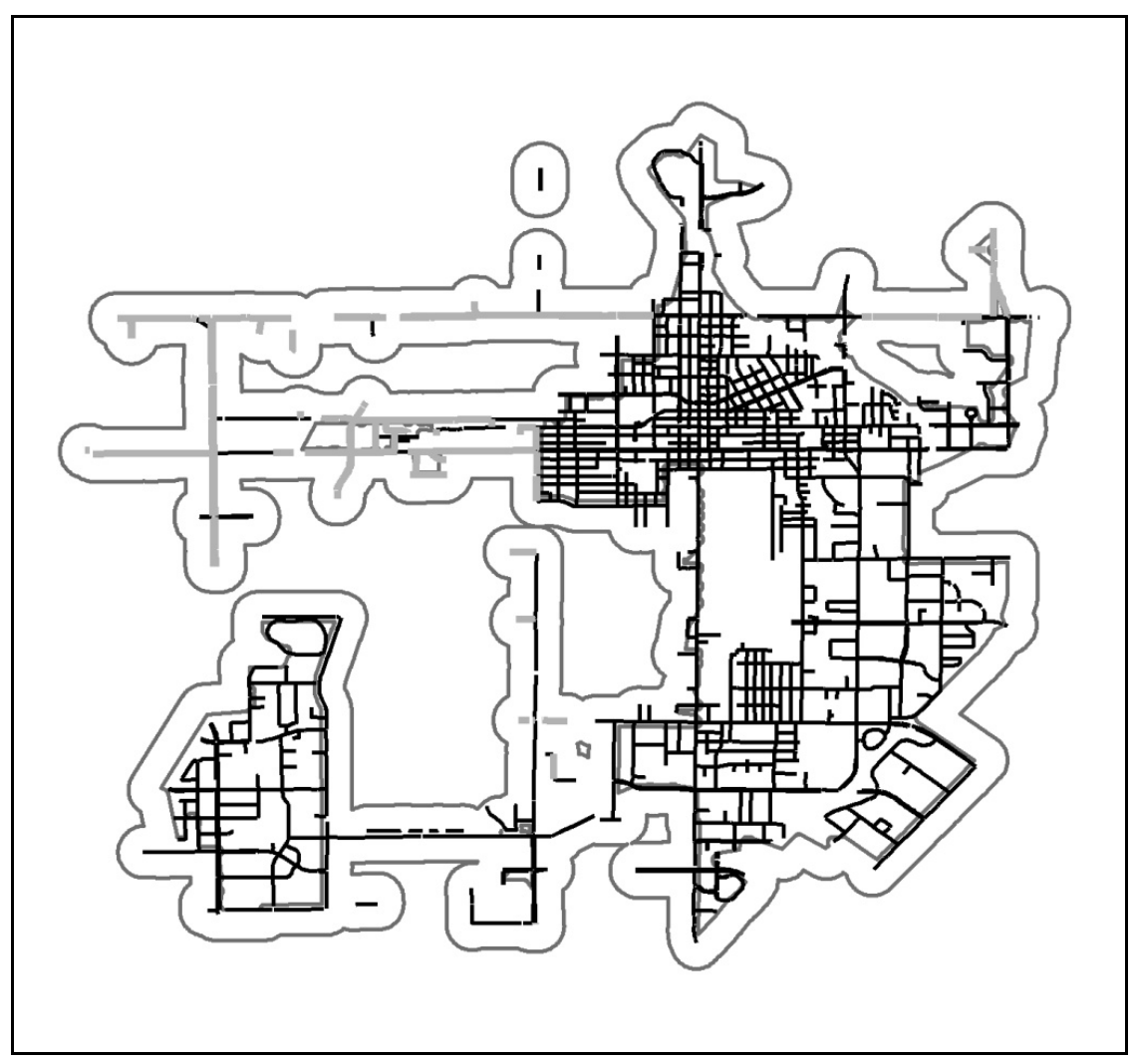


Figure 4: Estimates of Effects of Enterprise Zone Designation on (Log) Level of Employment with Long Leads and Lags ${ }^{\mathrm{a}}$

\section{A. With Control Ring}

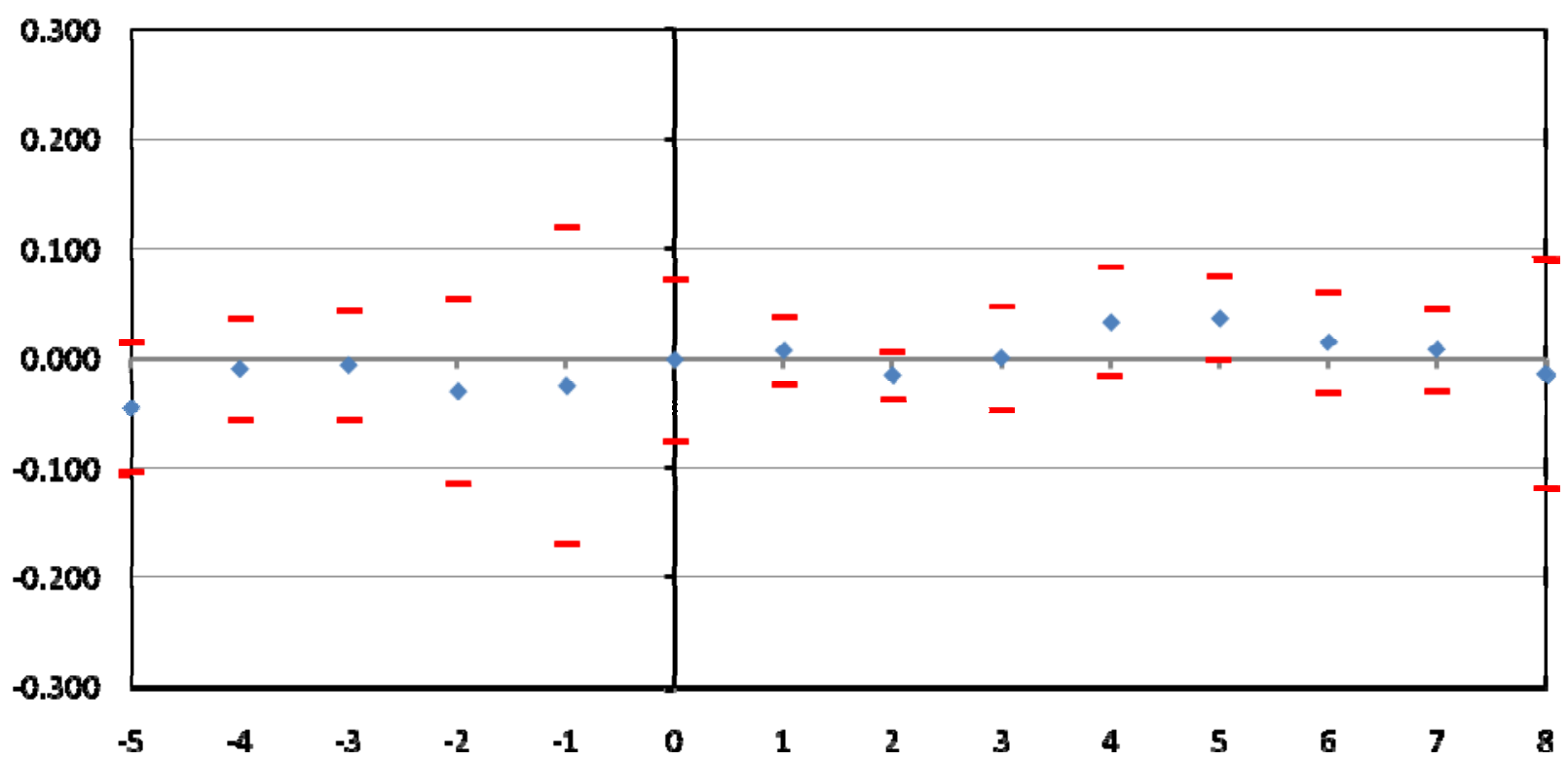

B. Without Control Ring

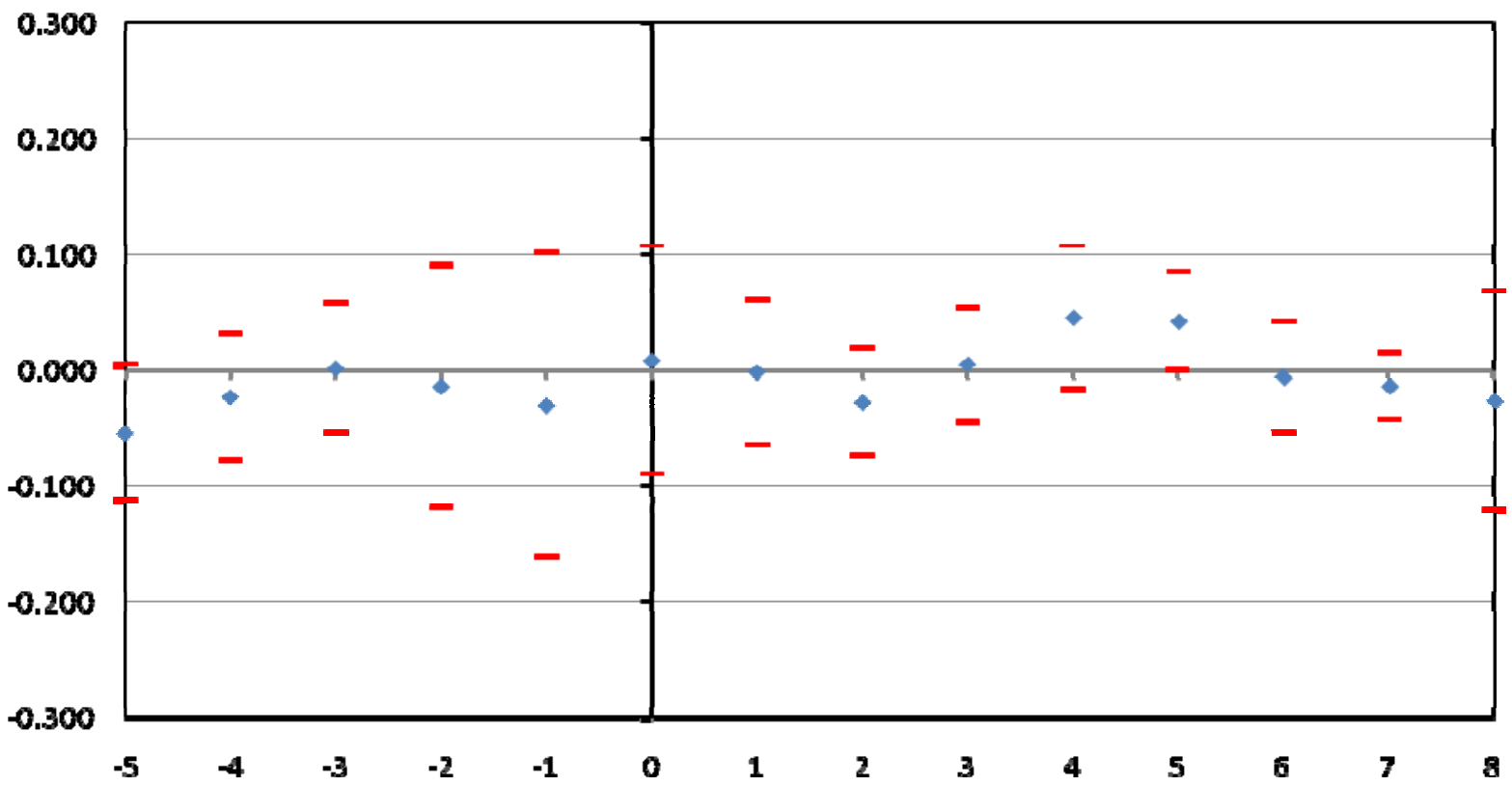

a Estimates are of equation (1), with five leads and eight lags of enterprise zone dummy variable added. The estimated lead effects are displayed to the left of zero - i.e., prior to enterprise zone designation at time zero - and the estimated lagged effects to the right. The diamonds plot the point estimates, and the bars plot the $95 \%$ confidence intervals based on clustered standard errors. 
Table 1: Current California Enterprise Zones and Year of Designation ${ }^{a}$

\begin{tabular}{|c|c|c|c|c|}
\hline $\begin{array}{l}\text { Enterprise zones included in the } \\
\text { study }\end{array}$ & Year of designation & $\begin{array}{l}\text { Number of } \\
\text { expansions in } \\
\text { the zone } \\
\end{array}$ & $\begin{array}{c}\text { Enterprise zones } \\
\text { not included in the } \\
\text { study }\end{array}$ & $\begin{array}{c}\begin{array}{c}\text { Year of } \\
\text { designation }\end{array} \\
\end{array}$ \\
\hline Altadena/Pasadena & 1992 & 1 & Agua Mansa & 1986 \\
\hline Bakersfield & 1986 & 3 & Antelope Valley & 1997 \\
\hline Coachella Valley & 1992 & 2 & Calexico & 1986 \\
\hline Delano & 1991 & 1 & Fresno & 1986 \\
\hline Eureka & 1986 & 1 & Kings County & 1993 \\
\hline Lindsay & 1997 & 0 & Pittsburg & 1988 \\
\hline Long Beach & 1992 & 1 & Stockton & 1993 \\
\hline Los Angeles & $\ldots$ & 14 & Watsonville & 1997 \\
\hline Los Angeles, Central City & 1986 & & Barstow & 2005 \\
\hline Los Angeles, East Side & 1988 & & Imperial Valley & 2005 \\
\hline Los Angeles, Harbor Area & 1989 & & Stanislaus & 2005 \\
\hline Los Angeles, Mid-Alameda & & & & \\
\hline Corridor & 1986 & & & \\
\hline Los Angeles, Northeast Valley & 1986 & & & \\
\hline Madera & 1989 & 0 & & \\
\hline Merced & 1991 & 1 & & \\
\hline Oakland & 1993 & 1 & & \\
\hline Oroville & 1991 & 1 & & \\
\hline Porterville & 1985 & 0 & & \\
\hline Richmond & 1992 & 1 & & \\
\hline Sacramento, Florin Perkins and & & & & \\
\hline Army Depot & 1989 & 2 & & \\
\hline Sacramento, Northgate / Norwood & 1989 & 2 & & \\
\hline San Diego, Barrio Logan & 1987 & 2 & & \\
\hline San Diego, Ysidro/Otay Mesa & 1991 & 3 & & \\
\hline San Francisco & 1992 & 4 & & \\
\hline San Jose & 1986 & 1 & & \\
\hline Santa Ana & 1993 & 1 & & \\
\hline Shafter & 1995 & 0 & & \\
\hline Shasta Metro & 1991 & 2 & & \\
\hline Shasta Valley & 1993 & 0 & & \\
\hline West Sacramento & 1988 & 0 & & \\
\hline Yuba/Sutter & 1986 & 4 & & \\
\hline
\end{tabular}

${ }^{a}$ The five Los Angeles zones are treated as one large zone for the analysis. In some cases the sources listed below provided different start dates. In the cases of such discrepancies, we checked with zone administrators to verify the start date. For Coachella, because the zone started in late 1991 (November 10), we use 1992 as the first year.

Sources: http://www.caez.org/Programs/Map_of_CA_Zones.html (viewed September 19, 2008); street address changes taken from street files, found at http://www.hcd.ca.gov/fa/cdbg/ez/enterprise (viewed November 1, 2006); Assembly Jobs, Economic Development, and the Economy Committee (2006). 
Table 2: Federal Designated Communities in California ${ }^{a}$

\begin{tabular}{|c|c|c|c|}
\hline $\begin{array}{l}\text { Date of } \\
\text { designation }\end{array}$ & $\begin{array}{l}\text { Date of } \\
\text { expiration }\end{array}$ & Program & $\begin{array}{l}\text { Overlapping state } \\
\text { enterprise zone }\end{array}$ \\
\hline $\begin{array}{l}12 / 21 / 1994 \\
12 / 21 / 1994\end{array}$ & $12 / 31 / 2009$ & $\begin{array}{l}\text { Round I Urban Enterprise Communities (65) } \\
\text { Los Angeles } \\
\text { Oakland } \\
\text { San Diego } \\
\text { San Francisco } \\
\text { Round I Supplemental Empowerment Zones (2) } \\
\text { Los Angeles } \\
\text { Round I Enhanced Enterprise Communities (4) } \\
\text { Oakland }\end{array}$ & $\begin{array}{l}\text { Los Angeles } \\
\text { Oakland } \\
\text { San Diego, Barrio Logan } \\
\text { San Francisco } \\
\text { Los Angeles } \\
\text { Oakland }\end{array}$ \\
\hline $12 / 21 / 1994$ & $12 / 31 / 2004$ & $\begin{array}{l}\text { Round I Rural Enterprise Communities (30) } \\
\text { City of Watsonville } \\
\text { Imperial County }\end{array}$ & $\begin{array}{l}\text { Watsonville } \\
\text { Calexico }\end{array}$ \\
\hline $\begin{array}{l}12 / 31 / 1998 \\
12 / 24 / 1998\end{array}$ & $\begin{array}{l}12 / 31 / 2009 \\
12 / 31 / 2009\end{array}$ & $\begin{array}{l}\text { Round II Urban Empowerment Zones (15) } \\
\text { Santa Ana } \\
\text { Round II Rural Empowerment Zones (5) } \\
\text { Desert Communities }\end{array}$ & $\begin{array}{l}\text { Santa Ana } \\
\text { Coachela Valley }\end{array}$ \\
\hline $\begin{array}{l}12 / 24 / 1998 \\
1 / 1 / 2002 \\
1 / 1 / 2002\end{array}$ & $\begin{array}{l}12 / 24 / 2009 \\
12 / 31 / 2009 \\
12 / 31 / 2009\end{array}$ & $\begin{array}{l}\text { Round II Rural Enterprise Communities (20) } \\
\text { Huron-Tule } \\
\text { Round III Urban Empowerment Zones (8) } \\
\text { Fresno } \\
\text { Urban Renewal Communities (28) } \\
\text { Orange Cove } \\
\text { Parlier }\end{array}$ & $\begin{array}{l}\text { Fresno } \\
\text { Fresno } \\
\text { Fresno } \\
\text { Fresno }\end{array}$ \\
\hline
\end{tabular}

${ }^{\mathrm{a}}$ The shaded regions correspond to federal zones that overlap the state enterprise zones included in our study. Although some zones changed status during the sample period, we treat the different federal zones as homogeneous, assigning to each zone the starting year for the first year they were designated federally. Los Angeles has both a Renewal Community and an Empowerment Zone. For our analysis we have appended these two together. The numbers in parentheses in the third column are the total number of federal zones designated in each round in the entire country. The Huron-Tule, Los Angeles, San Diego, and San Francisco Enterprise Communities became Renewal Communities in 2002.

Source: U.S. General Accounting Office (2004). 
Table 3: Descriptive Information on Zone Employment, $2004^{\mathrm{a}}$

\begin{tabular}{|c|c|c|c|c|}
\hline & $\begin{array}{c}\text { Employment } \\
\text { in enterprise } \\
\text { zone } \\
\end{array}$ & $\begin{array}{l}\text { Employment } \\
\text { in county }\end{array}$ & $\begin{array}{c}\text { Col. } 1 \text { share } \\
\text { of county } \\
\text { employment }\end{array}$ & $\begin{array}{c}\text { Col. } 1 \text { share } \\
\text { of state } \\
\text { employment }\end{array}$ \\
\hline & $(1)$ & $(2)$ & $(3)$ & $(4)$ \\
\hline Los Angeles & 274,434 & $4,677,221$ & 5.9 & 1.7 \\
\hline San Francisco & 215,329 & 600,488 & 35.9 & 1.3 \\
\hline Santa Ana & 175,018 & $1,733,164$ & 10.1 & 1.1 \\
\hline Oakland & 163,181 & 775,214 & 21.0 & 1.0 \\
\hline Long Beach & 121,754 & $4,677,221$ & 2.6 & 0.7 \\
\hline San Jose & 98,162 & 984,246 & 10.0 & 0.6 \\
\hline Sacramento, Florin Perkins and & & & & \\
\hline Army Depot & 40,832 & 624,638 & 6.5 & 0.2 \\
\hline Shasta Metro & 40,178 & 76,069 & 52.8 & 0.2 \\
\hline Altadena/Pasadena & 33,956 & $4,677,221$ & 0.7 & 0.2 \\
\hline San Diego, Barrio Logan & 28,624 & $1,440,987$ & 2.0 & 0.2 \\
\hline West Sacramento & 24,779 & 85,538 & 29.0 & 0.2 \\
\hline San Diego, Ysidro/Otay Mesa & 24,196 & $1,440,987$ & 1.7 & 0.1 \\
\hline Yuba/Sutter & 21,853 & 47,581 & 45.9 & 0.1 \\
\hline Richmond & 20,567 & 389,983 & 5.3 & 0.1 \\
\hline Eureka & 18,065 & 50,442 & 35.8 & 0.1 \\
\hline Sacramento, Northgate/Norwood & 15,279 & 624,638 & 2.4 & 0.1 \\
\hline Coachella Valley & 11,050 & 586,101 & 1.9 & 0.1 \\
\hline Madera & 9,765 & 38,635 & 25.3 & 0.1 \\
\hline Oroville & 8,954 & 81,353 & 11.0 & 0.1 \\
\hline Bakersfield & 8,829 & 242,303 & 3.6 & 0.1 \\
\hline Delano & 6,212 & 242,303 & 2.6 & 0.0 \\
\hline Shasta Valley & 5,818 & 18,777 & 31.0 & 0.0 \\
\hline Shafter & 3,695 & 242,303 & 1.5 & 0.0 \\
\hline Lindsay & 2,758 & 123,101 & 2.2 & 0.0 \\
\hline Porterville & 2,633 & 123,101 & 2.1 & 0.0 \\
\hline Merced & 641 & 68,050 & 0.9 & 0.0 \\
\hline Employment in all zones & $1,376,562$ & & & 8.4 \\
\hline Employment in control rings & 579,845 & & & 3.5 \\
\hline $\begin{array}{l}\text { Employment in all counties } \\
\text { with zones in our sample }\end{array}$ & $12,643,891$ & & & \\
\hline $\begin{array}{l}\text { Employment in all counties } \\
\text { with enterprise zones }\end{array}$ & $14,186,945$ & & & \\
\hline Statewide employment & $16,441,979$ & & & \\
\hline
\end{tabular}

${ }^{2}$ Figures are reported for the complete area of each zone as of 2004. In cases where a zone is mainly in one county but also extends into another county, in this table the zone is assigned to the county in which most of the zone is located. Note that some numbers repeat in column (2). This occurs when there are multiple zones in the same county. 
Table 4: Descriptive Statistics for Enterprise Zones and Control Ring, 1992

\begin{tabular}{|l|c|c|c|c|c|}
\hline & $\begin{array}{c}\text { Whole sample } \\
\text { (zones plus } \\
\text { control rings) }\end{array}$ & $\begin{array}{c}\text { Areas ever } \\
\text { included in } \\
\text { EZ's }\end{array}$ & $\begin{array}{c}\text { Areas included } \\
\text { in the original } \\
\text { EZ designations }\end{array}$ & $\begin{array}{c}\text { Areas included } \\
\text { in EZ } \\
\text { expansions }\end{array}$ & $\begin{array}{c}\text { 1,000-foot } \\
\text { control ring }\end{array}$ \\
\hline Employment (total) & $1,953,220$ & $1,349,629$ & 976,119 & 373,510 & 603,591 \\
\hline Establishments (total) & 140,969 & 96,752 & 71,006 & 25,746 & 44,217 \\
\hline $\begin{array}{l}\text { Employees per square } \\
\text { mile }\end{array}$ & 9,974 & 11,531 & 10,778 & 13,500 & 8,124 \\
\hline $\begin{array}{l}\text { Employees per } \\
\text { establishment } \\
\text { (weighted mean) }\end{array}$ & 14.6 & 14.7 & 14.2 & 16.2 & 14.3 \\
\hline $\begin{array}{l}\text { Share of employees in } \\
\text { low-wage industries } \\
\text { (weighted mean) }\end{array}$ & 11.6 & 11.8 & 11.6 & 12.4 & 10.9 \\
\hline $\begin{array}{l}\text { Share of employees in } \\
\text { manufacturing } \\
\text { (weighted mean) }\end{array}$ & 8.0 & 8.6 & 7.8 & 10.8 & 6.7 \\
\hline
\end{tabular}

Table 5: Descriptive Statistics on Employment and Establishment Growth, Within-Zone Comparisons ${ }^{\mathrm{a}}$

\begin{tabular}{|c|c|c|c|c|c|c|c|c|}
\hline & \multicolumn{2}{|c|}{ Unweighted } & \multicolumn{2}{|c|}{$\begin{array}{l}\text { Unweighted small } \\
\text { subzones }\end{array}$} & \multicolumn{2}{|c|}{$\begin{array}{c}\text { Unweighted large } \\
\text { subzones }\end{array}$} & \multicolumn{2}{|c|}{$\begin{array}{l}\text { Weighted by levels } \\
\text { in } 1992\end{array}$} \\
\hline & $\begin{array}{c}\text { Empl. } \\
(1)\end{array}$ & $\begin{array}{c}\text { Estab.'s } \\
(2)\end{array}$ & $\begin{array}{c}\text { Empl. } \\
(3)\end{array}$ & $\begin{array}{c}\text { Estab.'s } \\
(4)\end{array}$ & $\begin{array}{c}\text { Empl. } \\
(5)\end{array}$ & $\begin{array}{c}\text { Estab.'s } \\
(6)\end{array}$ & $\begin{array}{c}\text { Empl. } \\
(7)\end{array}$ & $\begin{array}{c}\text { Estab.'s } \\
(8)\end{array}$ \\
\hline $\begin{array}{l}\text { Enterprise subzones } \\
\text { after zone designation }\end{array}$ & & & & & & & & \\
\hline $\begin{array}{l}\text { Average annual percent } \\
\text { change, year of } \\
\text { designation through } \\
2004\end{array}$ & 2.3 & 1.8 & 4.4 & 1.6 & 0.2 & 2.1 & 0.3 & 2.1 \\
\hline $\begin{array}{l}\text { Enterprise subzones } \\
\text { prior to zone } \\
\text { designation }\end{array}$ & & & & & & & & \\
\hline $\begin{array}{l}\text { Average annual percent } \\
\text { change, } 1992 \text { through } \\
\text { year of designation }\end{array}$ & -0.6 & 1.4 & -3.3 & 0.7 & 2.2 & 2.2 & 0.8 & 1.8 \\
\hline
\end{tabular}

${ }^{\mathrm{a}}$ There is one observation for each year for each subzone. Only areas ever included in enterprise zones in the sample period are included in this table. In columns (3)-(6), "small" and "large" refer to below or above median employment (or number of establishments) in 1992. In columns (7) and (8) annual percentage changes are weighted using employment level (column (7)) or number of establishments (column (8)) in 1992. 
Table 6: Regression Estimates of Effects of Enterprise Zones ${ }^{\mathrm{a}}$

\begin{tabular}{|c|c|c|c|c|}
\hline & \multicolumn{2}{|c|}{ Including control rings } & \multicolumn{2}{|c|}{ No control rings } \\
\hline & $\begin{array}{c}\text { Employment } \\
\text { (1) }\end{array}$ & $\begin{array}{c}\text { Establishments } \\
\text { (2) }\end{array}$ & $\begin{array}{c}\text { Employment } \\
\text { (3) }\end{array}$ & $\begin{array}{c}\text { Establishments } \\
\text { (4) }\end{array}$ \\
\hline $\begin{array}{l}\text { A. Shift in level } \\
\text { Enterprise zone }\end{array}$ & $\begin{array}{l}-0.017 \\
(0.047)\end{array}$ & $\begin{array}{l}-0.022 \\
(0.024)\end{array}$ & $\begin{array}{l}-0.012 \\
(0.035)\end{array}$ & $\begin{array}{l}-0.042 \\
(0.021)^{*}\end{array}$ \\
\hline $\begin{array}{l}\text { B. Model A, subzone-specific linear } \\
\text { trends } \\
\text { Enterprise zone }\end{array}$ & $\begin{array}{c}0.012 \\
(0.051)\end{array}$ & $\begin{array}{l}0.029^{\dagger} \\
(0.022)\end{array}$ & $\begin{array}{c}0.018 \\
(0.077)\end{array}$ & $\begin{array}{c}0.015 \\
(0.020)\end{array}$ \\
\hline $\mathrm{N}($ panels A-B) & 1,300 & 1,300 & 962 & 962 \\
\hline $\begin{array}{l}\text { C. Shift in growth rate } \\
\text { Enterprise zone }\end{array}$ & $\begin{array}{c}0.004 \\
(0.009)\end{array}$ & $\begin{array}{l}-0.002 \\
(0.002)\end{array}$ & $\begin{array}{c}0.009 \\
(0.016)\end{array}$ & $\begin{array}{c}0.004 \\
(0.005)\end{array}$ \\
\hline $\begin{array}{l}\text { D. Model C, subzone-specific linear } \\
\text { trends } \\
\text { Enterprise zone }\end{array}$ & $\begin{array}{c}0.009 \\
(0.031) \\
\end{array}$ & $\begin{array}{c}-0.006^{\dagger \dagger \dagger} \\
(0.004)\end{array}$ & $\begin{array}{c}0.007 \\
(0.039) \\
\end{array}$ & $\begin{array}{l}-0.008^{\dagger \dagger} \\
(0.005)\end{array}$ \\
\hline $\begin{array}{l}\text { E. Shift in growth rate and level } \\
\text { Enterprise zone (growth rate) } \\
\text { Enterprise zone (level) }\end{array}$ & $\begin{array}{l}0.004 \\
(0.008) \\
-0.008 \\
(0.022)\end{array}$ & $\begin{array}{l}-0.002 \\
(0.002) \\
-0.005 \\
(0.003)^{*}\end{array}$ & $\begin{array}{c}0.009 \\
(0.014) \\
-0.004 \\
(0.038)\end{array}$ & $\begin{array}{c}0.004 \\
(0.005) \\
-0.008 \\
(0.004)^{*}\end{array}$ \\
\hline $\begin{array}{l}\text { F. Model E, subzone-specific linear } \\
\text { trends } \\
\text { Enterprise zone (growth rate) } \\
\text { Enterprise zone (level) }\end{array}$ & $\begin{array}{c}0.010 \\
(0.029) \\
-0.009 \\
(0.025)\end{array}$ & $\begin{array}{l}-0.006^{\dagger \dagger} \\
(0.004) \\
-0.002 \\
(0.003)\end{array}$ & $\begin{array}{c}0.008 \\
(0.035) \\
-0.006 \\
(0.041)\end{array}$ & $\begin{array}{l}-0.008 \\
(0.006) \\
0.0004 \\
(0.004)\end{array}$ \\
\hline $\mathrm{N}$ (panels C-F) & 1,200 & 1,200 & 888 & 888 \\
\hline
\end{tabular}

${ }^{a}$ Each column and panel reports estimates of the enterprise zone effects from a separate regression. The differences in the specification are explained in the panel headings. The dependent variables are in logs, substituting ones for zeros in levels prior to taking logs. The other control variables included are explained in the text; Panels A, B, and C report estimates of equations (1), (2), and (3), respectively. There are 26 zones, with the total number of initial zone designations and expansions adding to 74. Thus, because we have 13 years of data, when we do the analysis without control rings, and in levels (Panels A and $\mathrm{B})$, we have 962 observations $(74 \times 13)$. When we include a control ring for each zone, we have 1,300 observations $(\{74+$ $26\} \times 13$ ). We lose one observation on each subzone in Panels C-F, because we have to compute growth rates. Standard cluster-robust standard errors (clustering on enterprise zones) are in parentheses; ***,** and * indicate that the estimated coefficient is significant at the 1-, 5- or 10-percent level based on these standard errors. Cluster-robust wild bootstrapped confidence intervals for the $t$-statistic were also computed for the enterprise zone treatment variables, based on 1,000 replications; $\dagger \dagger \dagger, \dagger \dagger$ and $\dagger$ indicate that the estimated coefficient is significant at the 1-, 5- or 10-percent level based on the 99, 95-, and 90-percent confidence intervals, respectively. All estimates are weighted by 1992 employment levels (columns (1) and (3)) or number of establishments (columns (2) and (4)) in each subzone. 
Table 7: Employment in Enterprise Zones, Redevelopment Areas and Federal Designated Zones, 2004 $^{\mathrm{a}}$

\begin{tabular}{|l|c|c|}
\hline & $\begin{array}{c}\text { \% of enterprise } \\
\text { zone employment } \\
\text { in redevelopment } \\
\text { areas }\end{array}$ & $\begin{array}{c}\text { \% of enterprise } \\
\text { zone } \\
\text { employment in } \\
\text { federal zones }\end{array}$ \\
\hline Altadena/Pasadena & 11.6 & $\ldots$ \\
Bakersfield & 60.2 & $\ldots$ \\
Coachella Valley & 79.6 & 18.4 \\
Delano & 70.4 & $\ldots$ \\
Eureka & 58.1 & $\ldots$ \\
Lindsay & $\ldots$ & $\ldots$ \\
Long Beach & 63.4 & $\ldots$ \\
Los Angeles & 44.8 & 30.5 \\
Madera & 70.4 & $\ldots$ \\
Merced & 28.5 & $\ldots$ \\
Oakland & 82.8 & $\ldots$ \\
Oroville & 88.4 & $\ldots$ \\
Porterville & 37.1 & $\ldots$ \\
Richmond & 55.5 & $\ldots$ \\
Sacramento, Florin Perkins and Army Depot & 34.1 & $\ldots$ \\
Sacramento, Northgate/Norwood & 13.8 & $\ldots$ \\
San Diego, Barrio Logan & 52.1 & $\ldots$ \\
San Diego, Ysidro/Otay Mesa & 17.0 & $\ldots$ \\
San Francisco & 15.3 & $\ldots$ \\
San Jose & 59.5 & $\ldots$ \\
Santa Ana & 68.1 & $\ldots$ \\
Shafter & 88.3 & $\ldots$ \\
Shasta Metro & 67.5 & $\ldots$ \\
Shasta Valley & 92.5 & $\ldots$ \\
West Sacramento & 93.3 & $\ldots$ \\
Yuba/Sutter & $\ldots .5$ \\
It possba & $\ldots$ \\
\hline
\end{tabular}

${ }^{a}$ It is possible for a redevelopment area or federal zone to overlap only with an enterprise zone's control ring, in which case none of the enterprise zone's employment would be in the redevelopment area or federal zone. 
Table 8: Regression Estimates of Enterprise Zones Accounting for Redevelopment Areas or Federal Zones, Including Control Rings ${ }^{\mathrm{a}}$

\begin{tabular}{|c|c|c|c|c|}
\hline & \multicolumn{2}{|c|}{ Redevelopment areas } & \multicolumn{2}{|c|}{ Federal zones } \\
\hline & $\begin{array}{c}\text { Employment } \\
(1)\end{array}$ & $\begin{array}{c}\text { Establishments } \\
(2) \\
\end{array}$ & $\begin{array}{c}\text { Employment } \\
(3)\end{array}$ & $\begin{array}{c}\text { Establishments } \\
(4) \\
\end{array}$ \\
\hline \multicolumn{5}{|l|}{ A. Shift in level } \\
\hline Enterprise zone & $\begin{array}{l}-0.001 \\
(0.034)\end{array}$ & $\begin{array}{l}-0.015 \\
(0.019)\end{array}$ & $\begin{array}{l}-0.015 \\
(0.032)\end{array}$ & $\begin{array}{l}-0.018 \\
(0.023)\end{array}$ \\
\hline Redevelopment area/federal zone & $\begin{array}{l}-0.027 \\
(0.039)\end{array}$ & $\begin{array}{r}-0.0004 \\
(0.022)\end{array}$ & $\begin{array}{l}-0.051 \\
(0.052)\end{array}$ & $\begin{array}{c}0.013 \\
(0.014)\end{array}$ \\
\hline $\begin{array}{l}\text { Enterprise zone } \times \text { redevelopment } \\
\text { area/federal zone }\end{array}$ & $\begin{array}{l}-0.050 \\
(0.053)\end{array}$ & $\begin{array}{l}-0.020 \\
(0.021)\end{array}$ & $\begin{array}{l}-0.005 \\
(0.101)\end{array}$ & $\begin{array}{l}-0.030 \\
(0.021)\end{array}$ \\
\hline $\begin{array}{l}\text { Effect of enterprise zone in } \\
\text { redevelopment area/federal zone }\end{array}$ & $\begin{array}{l}-0.051 \\
(0.076)\end{array}$ & $\begin{array}{l}-0.035 \\
(0.031)\end{array}$ & $\begin{array}{l}-0.020 \\
(0.118)\end{array}$ & $\begin{array}{l}-0.048 \\
(0.020)^{* *}\end{array}$ \\
\hline $\mathrm{N}$ & 4,667 & 4,667 & 1,664 & 1,664 \\
\hline \multicolumn{5}{|l|}{ B. Shift in growth rate } \\
\hline Enterprise zone & $\begin{array}{c}0.003 \\
(0.011)\end{array}$ & $\begin{array}{l}-0.001 \\
(0.001)\end{array}$ & $\begin{array}{l}-0.001 \\
(0.005)\end{array}$ & $\begin{array}{l}-0.003 \\
(0.002)\end{array}$ \\
\hline Redevelopment area/federal zone & $\begin{array}{l}-0.001 \\
(0.010)\end{array}$ & $\begin{array}{l}-0.002 \\
(0.004)\end{array}$ & $\begin{array}{l}-0.018 \\
(0.010)^{*}\end{array}$ & $\begin{array}{l}-0.003 \\
(0.002)\end{array}$ \\
\hline Enterprise zone $\times$ redevelopment & 0.001 & -0.003 & 0.018 & 0.002 \\
\hline area/federal zone & $(0.013)$ & $(0.004)$ & $(0.014)$ & $(0.004)$ \\
\hline Effect of enterprise zone in & 0.004 & -0.004 & 0.017 & -0.001 \\
\hline redevelopment area/federal zone & $(0.004)$ & $(0.004)$ & $(0.018)$ & $(0.004)$ \\
\hline $\mathrm{N}$ & 4,308 & 4,308 & 1,536 & 1,536 \\
\hline
\end{tabular}

${ }^{a}$ Each column and panel reports estimates of the enterprise zone effects from a separate regression. See notes to Table 6 for additional details. The fourth row (labeled "Effect of enterprise zone in redevelopment area/federal zone") reports the estimated sum of the coefficients in the first and third rows of each panel. When we expand the analysis to account for redevelopment areas, we have a total of 255 distinct enterprise zone-redevelopment area designations or expansions, and 78 designations or expansions of redevelopment areas in the enterprise zone control rings. Thus, we have 4,667 observations $(\{255+26+78\} \times 13)$ when the enterprise zone control rings are included. When we expand the analysis to account for federal zones, we have a total of 96 distinct enterprise zone-federal zone designations or expansions, and 6 designations or expansions in control rings, for a total of 1,664 observations $(\{96+26+6\} \times 13)$ when the control rings are included. We lose one observation on each subzone in Panel B, because we have to compute growth rates. Standard cluster-robust standard errors (clustering on enterprise zones) are in parentheses; $* * *, * *$ and * indicate that the estimated coefficient is significant at the 1-, 5 - or 10-percent level based on these standard errors. Cluster-robust wild bootstrapped confidence intervals for the $t$-statistic were also computed for the enterprise zone variables, based on 1,000 replications; $\dagger \dagger \dagger$, $\dagger \dagger$ and $\dagger$ indicate that the estimated coefficient is significant at the 1-, 5- or 10-percent level based on the 99-, 95-, and 90-percent confidence intervals, respectively. All estimates are weighted by 1992 employment levels (columns (1) and (3)) or number of establishments (columns (2) and (4)) in each subzone. 
Table 9: Regression Estimates of Effects of Enterprise Zones on Share of Employment in Low-Wage Industries and in Manufacturing ${ }^{\mathrm{a}}$

\begin{tabular}{|c|c|c|c|c|}
\hline & \multicolumn{2}{|c|}{ Low-wage industries } & \multicolumn{2}{|c|}{ Manufacturing } \\
\hline & $\begin{array}{l}\text { Including } \\
\text { control rings }\end{array}$ & $\begin{array}{l}\text { No control } \\
\text { rings }\end{array}$ & $\begin{array}{l}\text { Including } \\
\text { control rings }\end{array}$ & $\begin{array}{c}\text { No control } \\
\text { rings }\end{array}$ \\
\hline & $(1)$ & $(2)$ & (3) & $(4)$ \\
\hline $\begin{array}{l}\text { A. Shift in level } \\
\text { Enterprise zone }\end{array}$ & $\begin{array}{c}0.005 \\
(0.014)\end{array}$ & $\begin{array}{c}0.001 \\
(0.018)\end{array}$ & $\begin{array}{c}0.002 \\
(0.010)\end{array}$ & $\begin{array}{c}0.001 \\
(0.011)\end{array}$ \\
\hline $\begin{array}{l}\text { B. Model A, subzone-specific } \\
\text { linear trends } \\
\text { Enterprise zone }\end{array}$ & $\begin{array}{c}0.007 \\
(0.011)\end{array}$ & $\begin{array}{l}-0.001 \\
(0.014)\end{array}$ & $\begin{array}{c}0.009 \\
(0.007)\end{array}$ & $\begin{array}{c}0.012 \\
(0.008)\end{array}$ \\
\hline $\mathrm{N}$ (panels A-B) & 1,300 & 1,300 & 962 & 962 \\
\hline $\begin{array}{l}\text { C. Shift in growth rate } \\
\text { Enterprise zone }\end{array}$ & $\begin{array}{l}-0.001 \\
(0.001)\end{array}$ & $\begin{array}{l}-0.001 \\
(0.004)\end{array}$ & $\begin{array}{l}0.0003 \\
(0.001)\end{array}$ & $\begin{array}{l}0.005 \\
(0.002)^{* *}\end{array}$ \\
\hline $\begin{array}{l}\text { D. Model C, subzone-specific } \\
\text { linear trends } \\
\text { Enterprise zone }\end{array}$ & $\begin{array}{l}-0.003 \\
(0.005)\end{array}$ & $\begin{array}{l}-0.002 \\
(0.007)\end{array}$ & $\begin{array}{c}0.003 \\
(0.003) \\
\end{array}$ & $\begin{array}{c}0.008 \\
(0.003)^{* *}, \dagger\end{array}$ \\
\hline $\begin{array}{l}\text { E. Shift in growth rate and } \\
\text { level } \\
\text { Enterprise zone (growth rate) } \\
\text { Enterprise zone (level) }\end{array}$ & $\begin{array}{l}-0.001 \\
(0.001) \\
-0.004 \\
(0.003) \\
\end{array}$ & $\begin{array}{c}-0.001 \\
(0.004) \\
-0.009 \\
(0.002)^{* * *, \dagger}\end{array}$ & $\begin{array}{l}0.0003 \\
(0.001) \\
-0.001 \\
(0.005) \\
\end{array}$ & $\begin{array}{l}0.005 \\
(0.002)^{* *} \\
-0.002 \\
(0.005)\end{array}$ \\
\hline $\begin{array}{l}\text { F. Model E, subzone-specific } \\
\text { linear trends } \\
\text { Enterprise zone (growth rate) } \\
\text { Enterprise zone (level) }\end{array}$ & $\begin{array}{l}-0.002 \\
(0.004) \\
-0.004 \\
(0.003)\end{array}$ & $\begin{array}{c}-0.0002 \\
(0.007) \\
-0.008 \\
(0.003)^{* * *, \dagger \dagger}\end{array}$ & $\begin{array}{c}0.003 \\
(0.003) \\
0.001 \\
(0.005)\end{array}$ & $\begin{array}{c}0.008 \\
(0.003)^{* *}, \dagger \dagger \\
-0.001 \\
(0.005)\end{array}$ \\
\hline $\mathrm{N}$ (panels C-F) & 1,200 & 888 & 1,200 & 888 \\
\hline
\end{tabular}

${ }^{a}$ Each column and panel reports estimates of the enterprise zone effects from a separate regression. See notes to Table 6 for additional details. The dependent variables are the shares of employment in low-wage industries or manufacturing. Standard cluster-robust standard errors (clustering on enterprise zones) are in parentheses; ***, ** and * indicate that the estimated coefficient is significant at the 1-, 5- or 10-percent level based on these standard errors. Cluster-robust wild bootstrapped confidence intervals for the $t$-statistic were also computed for the enterprise zone variables, based on 1,000 replications; $\uparrow \dagger \dagger$, $\dagger \dagger$ and $\dagger$ indicate that the estimated coefficient is significant at the 1-, 5- or 10-percent level based on the 99-, 95-, and 90-percent confidence intervals, respectively. All estimates are weighted by 1992 employment levels (columns (1) and (3)) or number of establishments (columns (2) and (4)) in each subzone. 
Table 10: Regression Estimates of Effects of Enterprise Zones, Sensitivity Analysis ${ }^{\mathrm{a}}$

\begin{tabular}{|c|c|c|c|c|c|c|c|c|}
\hline & \multicolumn{2}{|c|}{ Including control rings } & \multicolumn{2}{|c|}{ No control rings } & \multicolumn{2}{|c|}{ Including control rings } & \multicolumn{2}{|c|}{ No control rings } \\
\hline & $\begin{array}{l}\text { Empl. } \\
(1)\end{array}$ & $\begin{array}{c}\text { Estab.'s } \\
(2)\end{array}$ & $\begin{array}{c}\text { Empl. } \\
(3)\end{array}$ & $\begin{array}{c}\text { Estab.'s } \\
(4)\end{array}$ & $\begin{array}{c}\text { Empl. } \\
(5)\end{array}$ & $\begin{array}{c}\text { Estab.'s } \\
(6)\end{array}$ & $\begin{array}{c}\text { Empl. } \\
(7)\end{array}$ & $\begin{array}{c}\text { Estab.'s } \\
(8)\end{array}$ \\
\hline & \multicolumn{4}{|c|}{$\begin{array}{c}\text { Model A from Table } \mathbf{6} \\
\text { Estimated coefficient of enterprise zone (level) }\end{array}$} & \multicolumn{4}{|c|}{$\begin{array}{c}\text { Model C from Table } 6 \\
\text { Estimated coefficient of enterprise zone (growth rate) }\end{array}$} \\
\hline 1. Baseline (Table 6) & $\begin{array}{l}-0.017 \\
(0.047)\end{array}$ & $\begin{array}{l}-0.022 \\
(0.024)\end{array}$ & $\begin{array}{l}-0.012 \\
(0.035)\end{array}$ & $\begin{array}{c}-0.042 \\
(0.021)^{*}\end{array}$ & $\begin{array}{c}0.004 \\
(0.009)\end{array}$ & $\begin{array}{l}-0.002 \\
(0.002)\end{array}$ & $\begin{array}{l}0.009 \\
(0.016)\end{array}$ & $\begin{array}{c}0.004 \\
(0.005)\end{array}$ \\
\hline 2. 2,500-foot control ring & $\begin{array}{l}-0.022 \\
(0.034)\end{array}$ & $\begin{array}{l}-0.027 \\
(0.018)\end{array}$ & $\begin{array}{l}-0.012 \\
(0.035)\end{array}$ & $\begin{array}{c}-0.042 \\
(0.021)^{*}\end{array}$ & $\begin{array}{c}0.003 \\
(0.006)\end{array}$ & $\begin{array}{c}-0.004 \\
(0.002)^{* *}, \dagger \dagger\end{array}$ & $\begin{array}{c}0.009 \\
(0.016)\end{array}$ & $\begin{array}{c}0.004 \\
(0.005)\end{array}$ \\
\hline $\begin{array}{l}\text { 3. 1,000-foot control ring, include } \\
\text { questionable streets }\end{array}$ & $\begin{array}{l}-0.011 \\
(0.050)\end{array}$ & $\begin{array}{l}-0.022 \\
(0.024)\end{array}$ & $\begin{array}{l}-0.003 \\
(0.040)\end{array}$ & $\begin{array}{l}-0.043 \\
(0.021)^{*}\end{array}$ & $\begin{array}{c}0.005 \\
(0.009)\end{array}$ & $\begin{array}{l}-0.002 \\
(0.002)\end{array}$ & $\begin{array}{c}0.009 \\
(0.016)\end{array}$ & $\begin{array}{c}0.004 \\
(0.005)\end{array}$ \\
\hline $\begin{array}{l}\text { 4. 1,000-foot control ring, excluding 100- } \\
\text { foot buffer on either side of boundary }\end{array}$ & $\begin{array}{c}0.010 \\
(0.035)\end{array}$ & $\begin{array}{l}-0.024 \\
(0.030)\end{array}$ & $\begin{array}{c}0.008 \\
(0.041)\end{array}$ & $\begin{array}{l}-0.061 \\
(0.040)\end{array}$ & $\begin{array}{c}0.006 \\
(0.009)\end{array}$ & $\begin{array}{l}-0.003 \\
(0.002)\end{array}$ & $\begin{array}{l}-0.001 \\
(0.016)\end{array}$ & $\begin{array}{c}0.005 \\
(0.009)\end{array}$ \\
\hline 5. No weighting & $\begin{array}{l}-0.033 \\
(0.067)\end{array}$ & $\begin{array}{l}-0.048 \\
(0.056)\end{array}$ & $\begin{array}{l}-0.047 \\
(0.073)\end{array}$ & $\begin{array}{l}-0.038 \\
(0.066)\end{array}$ & $\begin{array}{c}0.014 \\
(0.009)^{\dagger}\end{array}$ & $\begin{array}{l}-0.010 \\
(0.007)\end{array}$ & $\begin{array}{c}0.050 \\
(0.030)^{\dagger \dagger}\end{array}$ & $\begin{array}{l}-0.001 \\
(0.019)\end{array}$ \\
\hline $\begin{array}{l}\text { 6. Weighting inversely by number of } \\
\text { sub-zones }\end{array}$ & $\begin{array}{l}-0.008 \\
(0.078) \\
\end{array}$ & $\begin{array}{l}-0.027 \\
(0.064) \\
\end{array}$ & $\begin{array}{c}-0.017 \\
(0.098)\end{array}$ & $\begin{array}{l}-0.011 \\
(0.080)\end{array}$ & $\begin{array}{c}0.014 \\
(0.009)^{\dagger}\end{array}$ & $\begin{array}{l}-0.011 \\
(0.005)^{* *}, \dagger \dagger \\
\end{array}$ & $\begin{array}{c}0.062 \\
(0.031)^{*}, \dagger \dagger \\
\end{array}$ & $\begin{array}{c}0.001 \\
(0.019) \\
\end{array}$ \\
\hline 7. Estimates dropping LA & $\begin{array}{c}0.046 \\
(0.018)^{* *, \dagger}\end{array}$ & $\begin{array}{l}-0.002 \\
(0.032)\end{array}$ & $\begin{array}{c}0.033 \\
(0.040)\end{array}$ & $\begin{array}{l}-0.028 \\
(0.044)\end{array}$ & $\begin{array}{c}0.012 \\
(0.006)^{*}\end{array}$ & $\begin{array}{c}-0.004 \\
(0.003)\end{array}$ & $\begin{array}{c}0.033 \\
(0.018)^{*}, \dagger \dagger\end{array}$ & $\begin{array}{l}-0.001 \\
(0.010)\end{array}$ \\
\hline 8. Estimates dropping LARZ & $\begin{array}{c}-0.015 \\
(0.047)\end{array}$ & $\begin{array}{l}-0.019 \\
(0.023)\end{array}$ & $\begin{array}{l}-0.009 \\
(0.034)\end{array}$ & $\begin{array}{c}-0.039 \\
(0.021)^{*}\end{array}$ & $\begin{array}{c}0.005 \\
(0.009) \\
\end{array}$ & $\begin{array}{l}-0.001 \\
(0.002)\end{array}$ & $\begin{array}{c}0.008 \\
(0.016)\end{array}$ & $\begin{array}{c}0.003 \\
(0.005)\end{array}$ \\
\hline 9. EZ initial designations or expansions & $\begin{array}{l}-0.019 \\
(0.054)\end{array}$ & $\begin{array}{l}-0.025 \\
(0.027)\end{array}$ & $\ldots$ & $\ldots$ & $\begin{array}{c}0.002 \\
(0.009)\end{array}$ & $\begin{array}{l}-0.003 \\
(0.004)\end{array}$ & $\ldots$ & $\ldots$ \\
\hline EZ initial designations only & $\begin{array}{c}0.018 \\
(0.085)\end{array}$ & $\begin{array}{c}0.021 \\
(0.045)\end{array}$ & .. & .. & $\begin{array}{c}0.003 \\
(0.005)\end{array}$ & $\begin{array}{c}0.001 \\
(0.004)\end{array}$ & .. & $\cdots$ \\
\hline 10. EZ status pre-1997 & $\begin{array}{l}-0.026 \\
(0.027)\end{array}$ & $\begin{array}{l}-0.015 \\
(0.027)\end{array}$ & $\begin{array}{c}-0.007 \\
(0.026)\end{array}$ & $\begin{array}{c}-0.042 \\
(0.023)^{*}\end{array}$ & $\begin{array}{l}0.0003 \\
(0.008)\end{array}$ & $\begin{array}{c}0.004 \\
(0.003)^{\dagger}\end{array}$ & $\begin{array}{c}0.003 \\
(0.016)\end{array}$ & $\begin{array}{c}0.002 \\
(0.006)\end{array}$ \\
\hline EZ status 1997 and after & $\begin{array}{l}-0.007 \\
(0.086)\end{array}$ & $\begin{array}{l}-0.029 \\
(0.023)\end{array}$ & $\begin{array}{l}-0.035 \\
(0.088)\end{array}$ & $\begin{array}{c}-0.040 \\
(0.014)^{* * *}\end{array}$ & $\begin{array}{c}0.006 \\
(0.014)\end{array}$ & $\begin{array}{c}-0.005 \\
(0.004)^{\dagger}\end{array}$ & $\begin{array}{c}0.021 \\
(0.017)^{\dagger \dagger}\end{array}$ & $\begin{array}{c}0.007 \\
(0.009)\end{array}$ \\
\hline
\end{tabular}

${ }^{\mathrm{a}}$ Each column and panel reports estimates of the enterprise zone effects from a separate regression. See notes to Table 6 for additional details. The sample sizes are as in Table 6, except that in Panel 7 the sample sizes fall to 1,092 and 767 (with and without control rings). The differences in the specification are explained in the panel headings. Standard cluster-robust standard errors (clustering on enterprise zones) are in parentheses; $* * *, * *$ and $*$ indicate that the estimated coefficient is significant at the 1-, 5- or 10-percent level based on these standard errors. Cluster-robust wild bootstrapped confidence intervals for the $t$-statistic were also computed for the enterprise zone variables, based on 1,000 replications; $\dagger \dagger+, \dagger$ and $\dagger$ indicate that the estimated coefficient is significant at the 1-, 5- or 10-percent level based on the 99-, 95-, and 90percent confidence intervals, respectively. All estimates are weighted by 1992 employment levels (odd-numbered columns) or number of establishments (even-numbered columns) in each subzone. 